\title{
ACACIA AURICULIFORMIS-EXTRACT SYNTHESIS PR-PROTEINS DEVELOPED POTENTIAL BIOMEDICINES-VACCINE AGAINST OKRA-DISEASES AND COVID-19: IMPROVED SCIENCE TECHNOLOGY COMMUNICATIONS BIO-ECONOMY APPLICATIONS
}

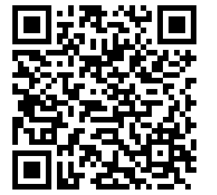

\author{
Subhas Chandra Datta Ph.D. ${ }^{*} \bowtie$ iD \\ ${ }^{* 1}$ Headmaster, Secretary and Researcher, Eco-club Research Unit, Kanchannagar D.N. das High \\ School (HS), Kanchannagar, Burdwan Municipality, Purba Bardhaman, Burdwan-713102, \\ Department of Zoology, Visva Bharati, Sriniketan-731235 West Bengal, India
}

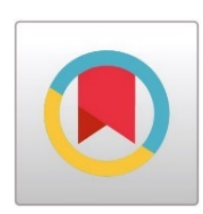

DOI: https://doi.org/10.29121/granthaalayah.v8.i10.2020.1893

Article Type: Research Article

Article Citation: Subhas Chandra Datta Ph.D.. (2020). ACACIA AURICULIFORMIS-EXTRACT SYNTHESIS PR-PROTEINS DEVELOPED POTENTIAL BIOMEDICINES-VACCINE AGAINST OKRA-DISEASES AND COVID-19: IMPROVED SCIENCE TECHNOLOGY COMMUNICATIONS BIO-ECONOMY APPLICATIONS. International Journal of Research GRANTHAALAYAH, 8(10), 249-270. https://doi.org/10.29121/granthaa layah.v8.i10.2020.1893

Received Date: 04 October 2020

Accepted Date: 31 October 2020

\section{Keywords:}

Acacia Auriculiformis-Extract Synthesis-PR-Proteins Developed-Potential-BiomedicinesVaccine Okra-Diseases-and-COVID-19 Improved-Science-TechnologyCommunications Bio-Economy-Applications

\section{ABSTRACT}

The pandemic COVID19, effects on global health, educations, clinical research, human civilization, and the economy. So, it has been an urgency to develop proper vaccines against coronavirus. India emphasis on the most nutritious economicallyimportant number-one-consumption-vegetable, okra, used in many human diseases, is naturally infected by different pathogens and significantly reduces production. Though pesticides are the most effective means of control, but they are expensive and toxic to the environment. So, it will require new and more efficient solutions, technologies, products, and methods. Present pre- and post-treatment with biomedicines; Acacia auriculiformis-extract, prepared from the funicles of Acacia auriculiformis A. Cunn., dissolved in sterile tap water at $1 \mathrm{mg} / 10 \mathrm{ml}$, were applied by foliar spray once daily for 15 days @ $10 \mathrm{ml} /$ plant, against Root-Knot (RK), Yellow Vein Mosaic Virus (YVMV) and Okra Enation Leaf Curl Virus (OELCV) diseases of okra, (Abelmoschus esculentus L. Moench) cv.Ankur-40. The soluble root-proteins were separated by using sodium dodecyl sulfate-polyacrylamide gel electrophoresis (SDS-PAGE) and were scanned with a recording densitometer electrophoretic scanner, measuring the molecular weight of proteins. Pre- and post-treatment with high-diluted-biomedicines; Acacia auriculiformis extract, were highly effective in reducing different okra-diseases by synthesis of new pathogenesis-related-protein (PR-proteins), inducing their natural defenseresponse against pathogens-infection and enhanced their growth as well as protein content of fruits and roots. The high-diluted-biomedicines; Acacia auriculiformis extract, not only used as a potential-biomedical-drugs or vaccine against various plant-diseases, by synthesis of new PR-proteins, increasing natural-defense-response, but also, it may help for the preparation of a vaccine against COVID-19, by increasing immunity and enriching science and technology communications applications, cost-effectiveness and biodiversity conservations as well as bio-economy-applications issues, reviving human civilizations in the old form. And in near future okra may itself be a 'Potential Biomedicine as well as Vaccine' and world will return in normal form by defeating COVID-19.

\section{INTRODUCTION}

The COVID19, pandemic problems [1], effects on our private, professional life, social life, and the socialorganization-communities [1], global health, travel, economy, and human civilization, as well as the clinical research,

(C) 2020 The Author(s). This is an open access article distributed under the terms of the Creative Commons Attribution License, which permits unrestricted use, distribution, and reproduction in any medium, provided the original author and source are credited. 
Acacia Auriculiformis-Extract Synthesis PR-Proteins Developed Potential Biomedicines-Vaccine Against Okra-Diseases and Covid-19: Improved Science Technology Communications Bio-Economy Applications

with scientists, has been an urgency to develop vaccines against coronavirus [2] for the unusual viral pneumonia in patients and different animals [3], forming the fifth endemic coronavirus, leaping from animals to humans, becoming a health danger [4]. It is reported that wildlife contains many coronaviruses that could potentially emerge in humans in the future due to very closely related animal-human virus [5], genetic resistance [6], divergence, structural and the future evolution, adaptation, and spread [7], prevails among humans for a long time as an asymptomatic patients [8], and recent, pandemic situation is analogous to war, the delay of every week in the deployment of a vaccine to the seven billion humans on earth will cost thousands of lives [9]. For this, WHO responses to the outbreak, the research and development blueprint has been activated to accelerate diagnostics, vaccines, and therapeutics for this novel coronavirus [10].

To meet the challenge of the pandemic problems, India emphasis on the most economically important number one consumption-vegetable crop [11], okra, used as traditional medicine, the 'Nature's Gift to human disease-free healthy life' [12], consumed in a variety of ways, fruits rich in vitamins, calcium, folic acid, carbohydrates, phosphorus, magnesium, and potassium [13], iodine, and other mineral matters, and a good source of superior nutritional quality -oil and -protein, unsaturated fatty acids such as linoleic acid, which is essential for human nutrition, and mature fruit and stems contain crude fiber, used in the paper industry, and the mucilage of roots- and stems- is used in the sugarcane industry of India achieved first in the world [13]. But recently, in India, the production in terms of yield as well as fruit quality of okra is hampered adversely by the naturally occurring Root-Knot (RK) diseases caused by the nematode-pathogens, Meloidogyne incognita (Kofoid and white, Chitwood, 1949), Yellow Vein Mosaic Virus (YVMV) disease- and Okra Enation Leaf Curl Virus (OELCV) disease-, caused by the virus-pathogens which spreads by an insect vector, named-whitefly (Bemisia tabaci Gen). The use of chemicals is the most effective means of control, but they are expensive and not environment-friendly creating health hazards [14], [15] and the genetics-resistance [16] to YVMV and OELCV in okra, and diversity of viruses affect the production, financial losses of okra, and climatic changes impact on the global economy [17], [18]. A number of plant -bioagents [19], [20], [21] or -bio-nematicides [15], [22], [23] and intercropping [24], [25], [26], [27], and biomedicine [28], [29], [30], [31] only stand as a suitable- and useful- against different plants-, animals- and human- diseases caused by pathogens. But it remains some problems [32], [33], [34], [35]. To meet the challenge of the problems; it is already reported that the Biomedicines; Aakashmoni or Acaciasides (A\&B) or Acacia auriculiformis extract, is being used traditionally to overcome various medical complications [14], [15], [19], [20], [21], [22], [28], [29], [30], [31], [33], due to presence of several medical ailments and effective bioactive phytoconstituents, and to its low toxicity and high efficacy [34], [35].

Now, to concur the both the pandemic-situations, the main aims and objectives were: to investigate new and more efficient solutions, technologies and products for controlling disease, by using biomedicines; Acacia auriculiformis-extract, prepared from the funicles of Acacia auriculiformis A. Cunn., with pre- and post-treatments, at an extremely low dose, under naturally infected very common; Root-Knot (RK), Yellow Vein Mosaic Virus (YVMV), and Okra Enation Leaf Curl Virus (OELCV) diseases of okra, (Abelmoschus esculentus L. Moench) cv. Ankur-40, in field trials, and to see the synthesis of new pathogenesis-related-protein (PR-proteins), which are separated by using sodium dodecyl sulfate-polyacrylamide gel electrophoresis (SDS-PAGE) and are scanned with recording densitometer electrophoretic scanner, measuring the molecular weight of the proteins. Primarily, it has been thought, though acaciasides will be the effective vaccine, but it has some cost, and takes time for preparation as well as application as a vaccine against COVID-19 [20], [33]. And to find out the most appropriate, economic, and sustainable treatment-methods against coronavirus, which may help to the preparation of a vaccine against the COVID-19 disease [1], [2], [3], [4] outbreak [9], [10] by improving our immune system [15], [19], [20], [21], [22], [28], [29], [30], [31], [33], [34], [35], [36], [37], [38].

\section{MATERIALS AND METHODS}

\subsection{PREPARATION OF BIOMEDICINES- ACACIA AURICULIFORMIS EXTRACT}

Air-dried and powdered funicles of Acacia auriculiformis A. Cunn. (Plate 1), was extracted with 90\% ethanol at room temperature $\left(25 \pm 2^{\circ} \mathrm{C}\right)$ for 15 days, filtered and removed by evaporation at room temperature $\left(25 \pm 2^{\circ} \mathrm{C}\right)$. The residue, obtained after removal of the solvent under reduced pressure, was dried in a desiccator over anhydrous 
Subhas Chandra Datta Ph.D.

calcium chloride[15], [19], [22], [23], [32], [35], [39] and the crude residues were dissolved in 90\% ethanol at $1 \mathrm{mg} / \mathrm{ml}$ concentration and was formed the Acacia auriculiformis-extract [31], [36], [37], [38], [39], [40], [41], [42], [43], [44], [45], [46], [47].

\subsection{PREPARATION OF THE PRE- AND POST-TREATMENT PLOTS}

The experiment was carried out in the garden of the Department of Zoology, Visva-Bharati, Santiniketan-731 235, West Bengal, India, at an ambient temperature $25 \pm 2{ }^{\circ} \mathrm{C}$ and RH 75 $\pm 5 \%$ [14], [15], [22], [23], [25], [30], [48]. Four concrete plots were a mixture of sandy soil and yard manure $(2: 1, \mathrm{v} / \mathrm{v})$. One untreated plot was treated with boiling water five times for dramatization and the other three plots were naturally infected with Meloidogyne incognita (Kofoid and White, Chitwood, 1949). For uniform distribution, in these three plots, soil and root samples were taken at random to determine the extent and intensity of $M$. incognita -pathogen infestation by mixing @ 2,37,000 2375 J2 / plot each (M. incognita juveniles) [14], [15], [22], [23], [25], [30], [48], [49], [50], [51], [52], [53], [54], [55], [56], [57], [58].

\subsection{PLANTATIONS}

Aseptically germinated seeds of okra (Abelmoschus esculentus L. cv. Ankur-40) were planted with a gap of $25 \mathrm{~cm}$ in the four plots and allowed to grow for a period of ninety-one days. The treatments-plots were: uninoculated untreated, inoculated untreated, Acacia auriculiformis-extract -pretreated, and -post-treated [15], [19], [20], [21], [22], [25], [26], [27], [28], [39], [40], [41], [42], [43], [44].

\subsection{MORTALITY TEST}

Two sets (for each test), of cavity blocks with $1 \mathrm{ml}$ distilled water containing 50 larvae (J2) of $M$. incognita were taken; one set was treated as control and the other was treated as treatment set. To assess the direct effect of biomedicines; Acacia auriculiformis-extract, by treatment -test solution (prepared by $1 \mathrm{mg} / 10 \mathrm{ml}$ distilled water), the water was removed by pipette from all the treatment sets, and immediately replaced by $1 \mathrm{ml}$ of pretreatment -test solutions of Acacia auriculiformis-extract, were added respectively. To assess the direct effect of the control solution, the control set was received $1 \mathrm{ml}$ of control solution and observed with every 30 minutes interval for a period of 12 hours exposure period at room temperature $\left(25 \pm 2^{\circ} \mathrm{C}\right)$. This mortality test was replicated five times. This mortality test was replicated five times [49], [50], [51], [52], [53], [54], [55], [56], [57], [58].

\subsection{PRE- AND POST-TREATMENT WITH ACACIA AURICULIFORMIS-EXTRACT}

The biomedicines; Acacia auriculiformis-extract, test- and -control solutions (1mg/10ml concentration): After 29-days, the Root-Knot (RK) diseases (Plate 2) [14,15] caused by the nematode-pathogens, Yellow Vein Mosaic Virus (YVMV) disease (Plate-3) and Okra Enation Leaf Curl Virus (OELCV) disease (Plate 4), caused by the virus-pathogens which spreads by an insect vector, named-whitefly (Bemisia tabaci Gen), are naturally occurred and at this 6-leaf stage of okra plants, all the diseases were assessed initially (before pretreatments), and pretreatments were done by foliar spray @10 ml/plant (1mg/10ml concentration) once daily for 15 days with; biomedicines Acacia auriculiformis-extract, -test solutions and -control solution respectively [31], [36], [37], [38], [39], [40], [41], [42], [43], [44], [45], [46], [47], [48].

\subsection{ANALYSIS OF RESIDUE}

The residues run in a thin layer chromatography plate (TLC) with the standard; Acacia auriculiformis extract, treatment test substances respectively [40], [41], [42], [43], [44], [45], [46], [47], [48]. 
Acacia Auriculiformis-Extract Synthesis PR-Proteins Developed Potential Biomedicines-Vaccine Against Okra-Diseases and Covid-19: Improved Science Technology Communications Bio-Economy Applications

\subsection{HARVESTING}

Ninety-one days after plantation of germinated seeds of okra, all the plants were uprooted from each plot and the parameters of growth and nematode infection such as biomass of shoot and root, root gall number, nematode population per gram of root and 200 soil, fruit and root total protein fraction in each sample was estimated [50], [51], [55], [56], [57]. At thirty days after the last pretreatment, all the parameters of diseases were assessed again (after last pretreatments) for each group and all the data were used for statistical analysis by Student t-test [31], [36], [37], [38], [39], [40], [41], [42], [43], [44], [45], [46], [47] and all the data were considered and were presented in Table 1.

\subsection{PREPARATION OF ROOT PROTEINS}

Fresh roots of okra plants of 4-groups were collected at random and root pieces were homogenized with distilled water using mortar and pestle followed by glass tube homogenizer [56], [57]. The extracts were then centrifuged at 3,500 rpm for 15 minutes at 40C in Remi C-24 refrigerated centrifuge and the supernatants were collected. All the samples were transferred into lyophilizer and after lyophilization, the powdery extract was stored (-200C) for protein separation [56], [57], [58], [59], [60].

\subsection{DENSITOMETER SCANNING}

Analysis of total soluble roots proteins separation was carried out essentially by the method of Laemmli [59], [60], by using one-dimensional vertical sodium dodecyl sulfate-polyacrylamide gel electrophoresis (SDS-PAGE), with the modification as suggested by the LKB Instructional Manual (1986). A 10\% separating gel and 5\% stacking gel were used. Samples for the preparation of electrophoretic run were mixed with $2 x$ treatment buffer. A sample of $65 \mu \mathrm{l}$ of root protein extract was loaded along with dye. The bands were scanned with recording electrophoretic scanner (Biomidi, 96-300 Densitometers, Pare de La Plaine, France). The observation was recorded from the densitometers scanning curve measuring the total number of root-proteins with molecular weight. Wide range markers (k) of Pharmacia United Ltd., Sweden, were used as the standard, for the molecular weight estimation of proteins [59], [60].

\subsection{SCIENCE AND TECHNOLOGY COMMUNICATIONS APPLICATIONS}

The activity and the importance of " Pre-and Post- Treatment with Acacia auriculiformis extract, at an Extremely Low Doses, Use as Potential Cost-Effective Biomedicines Against Various Pathogens including COVID-19: Enriching Science and Technology Communication Green-economy Applications and Healthcare-, Defense response- and Immunity- as well as Biodiversity Conservation- Issues" in different audiovisual media (TV channels), social media, web pages, newspapers, and journals are recorded, which is a platform to promote and discuss different new issues and developments by publishing [14], [15], [19], [20], [21], [22], [23], [24], [25], [26], [27], [28], [29], [30], [31], [32], [33], [61], [62], [63].

\subsection{DEVELOPMENT OF IDEAS FOR PREPARATION OF A VACCINES}

It will be achieved from typical analysis or justifications of literature review, reports of clinical research trials, or fields note. Then the development of new ideas or hypotheses for the preparation of vaccines against COVID-19, will arise and open the new window of future research for global-good health [14], [15], [19], [20], [21], [22], [23], [24], [25], [26], [27], [28], [29], [30], [31], [32], [33], [61], [62], [63]. 


\section{RESULTS}

\subsection{TOXICITY TEST ON MORTALITY}

The biomedicines; Acacia auriculiformis extract, at extremely low doses, had no direct toxic effects on nematodes mortality respectively.

\subsection{ANALYSIS OF RESIDUES TOXICITY}

Okra leaves and fruits, collected fifteen days after the last pretreatment did not contain any toxic residue of the biomedicines; Acacia auriculiformis extract.

\subsection{ROOT-KNOT AND FOLIAR DISEASES}

Table 1 shows the pre- and post-treatment effects of high diluted biomedicines; Acacia auriculiformis extract, at extremely low doses, on Root-Knot (RK) disease, and Yellow Vein Mosaic Virus (YVMV) and Okra Enation Leaf Curl Virus (OELCV) foliar diseases of okra plants, assessed initially (Day- 0) means before pretreatments and after a period of 30 days (Day -30) means after last posttreatment, in a field trial with the number of common-shared rootprotein in comparison to uninoculated untreated one ( $\mathrm{P}<0.01$ by ' $\mathrm{t}$ '- test). All the pretreatments with biomedicines; Acacia auriculiformis-extract, significantly reduced the root-knot and foliar diseases in comparison to the first two plots; uninoculated untreated (control) and inoculated untreated ones. Though, all the plant's groups, average; the number of leaves, number of nematodes in soil, biomass of shoots, and protein of fruits, are significantly increased than inoculated untreated plants group, but average; the biomass of roots, number of root galls and nematodes populations in roots and root protein content percent, is higher in the inoculated untreated one. The highest number of common-shared root proteins are seven in healthy uninoculated untreated control plants and the lowest number is one in the inoculated untreated one (Table 1 and Fig. 1).

Table 1: Effects of the Acacia auriculiformis extract treatments groups of okra plants infected with root-knot, YVMV and OELCV diseases

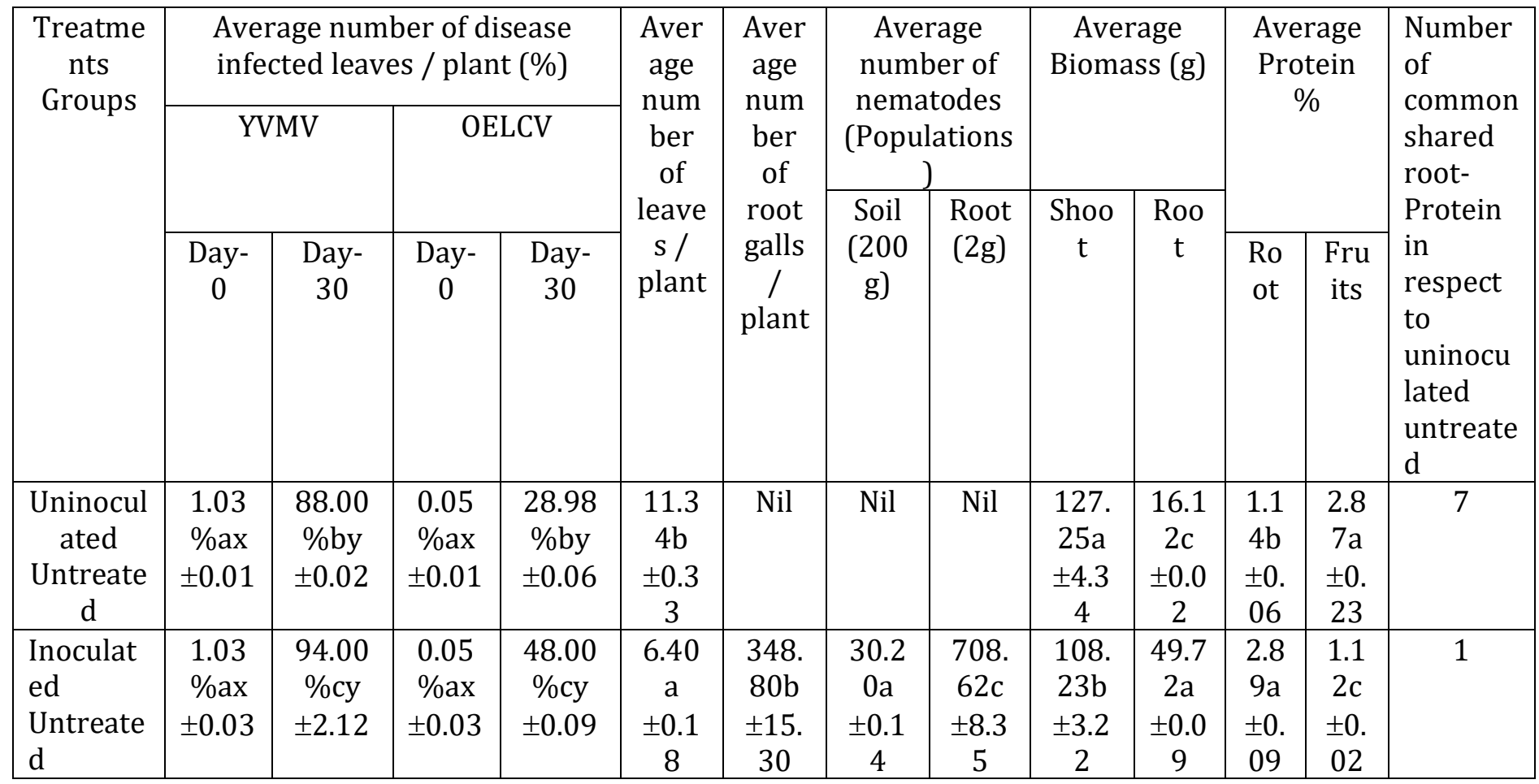


Acacia Auriculiformis-Extract Synthesis PR-Proteins Developed Potential Biomedicines-Vaccine Against Okra-Diseases and Covid-19: Improved Science Technology Communications Bio-Economy Applications

\begin{tabular}{|c|c|c|c|c|c|c|c|c|c|c|c|c|c|}
\hline $\begin{array}{c}\text { Acacia } \\
\text { auriculif } \\
\text { ormis } \\
- \\
\text { Pretreat } \\
\text { ed }\end{array}$ & $\begin{array}{c}1.03 \\
\% \mathrm{ax} \\
\pm 0.02\end{array}$ & $\begin{array}{c}3.01 \% \\
\quad \text { ay } \\
\pm 0.21\end{array}$ & $\begin{array}{c}0.05 \\
\% \mathrm{ax} \\
\pm 0.02\end{array}$ & $\begin{array}{c}0.84 \% \\
\quad \text { ay } \\
\pm 0.02\end{array}$ & $\begin{array}{c}15.7 \\
7 \mathrm{c} \\
\pm 0.3 \\
5\end{array}$ & $\begin{array}{c}29.1 \\
1 \mathrm{a} \\
\pm 0.4 \\
8\end{array}$ & $\begin{array}{c}534 . \\
68 b \\
\pm 4.6 \\
5\end{array}$ & $\begin{array}{c}32.0 \\
2 \mathrm{a} \\
\pm 0.4 \\
6\end{array}$ & $\begin{array}{c}127 . \\
12 \mathrm{a} \\
\pm 2.1 \\
1\end{array}$ & $\begin{array}{c}18.1 \\
2 \mathrm{~b} \\
\pm 1.7 \\
6\end{array}$ & $\begin{array}{c}0.9 \\
9 \mathrm{~b} \\
\pm 0 . \\
04\end{array}$ & $\begin{array}{c}2.6 \\
8 \mathrm{~b} \\
\pm 0 . \\
05\end{array}$ & 3 \\
\hline $\begin{array}{c}\text { Acacia } \\
\text { auriculif } \\
\text { ormis } \\
- \\
\text { Posttrea } \\
\text { ted }\end{array}$ & $\begin{array}{c}1.03 \\
\% \mathrm{ax} \\
\pm 0.02\end{array}$ & $\begin{array}{c}3.63 \% \\
\quad \text { ay } \\
\pm 0.03\end{array}$ & $\begin{array}{r}0.05 \\
\% \mathrm{ax} \\
\pm 0.02\end{array}$ & $\begin{array}{c}0.82 \% \\
\text { ay } \\
\pm 0.02\end{array}$ & $\begin{array}{c}15.6 \\
7 \mathrm{c} \\
\pm 0.3 \\
0\end{array}$ & $\begin{array}{c}30.2 \\
2 \mathrm{a} \\
\pm 0.4 \\
2\end{array}$ & $\begin{array}{c}520 . \\
02 \mathrm{~b} \\
\pm 5.3 \\
7\end{array}$ & $\begin{array}{c}36.9 \\
8 \mathrm{~b} \\
\pm 0.1 \\
6\end{array}$ & $\begin{array}{c}128 . \\
30 \mathrm{a} \\
\pm 4.2 \\
6\end{array}$ & $\begin{array}{c}18.0 \\
2 \mathrm{~b} \\
\pm 0.6 \\
7\end{array}$ & $\begin{array}{l}1.0 \\
7 \mathrm{~b} \\
\pm 0 . \\
02\end{array}$ & $\begin{array}{c}2.8 \\
4 \mathrm{~b} \\
\pm 0 . \\
02\end{array}$ & 2 \\
\hline
\end{tabular}

'a,b,c,d,e'- means different small letter in a column indicate significant difference $(\mathrm{P}<0.05)$ by ' $\mathrm{t}$ '-test.

' $\mathrm{x}, \mathrm{y}$ '- means different small letter in a row indicate significant difference between day-0 and day-30 $(\mathrm{P}<0.01)$ by ' $t$ '-test.

'Day-0' - means before pretreatment.

'Day-30' - means after posttreatment.

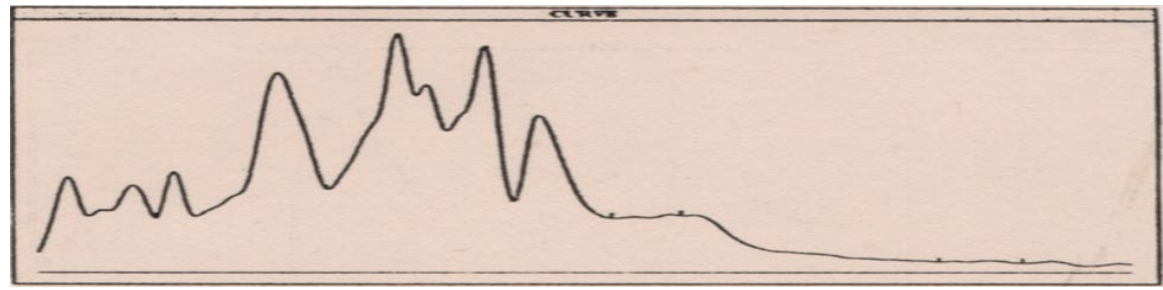

1a: Uninoculated Untreated

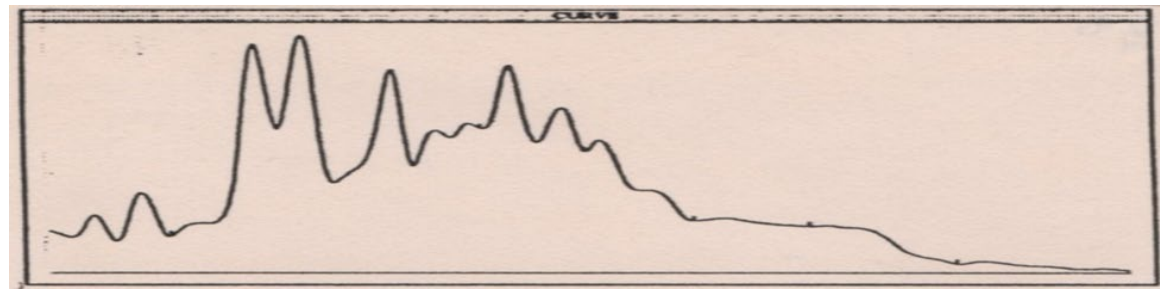

1b: Inoculated Untreated

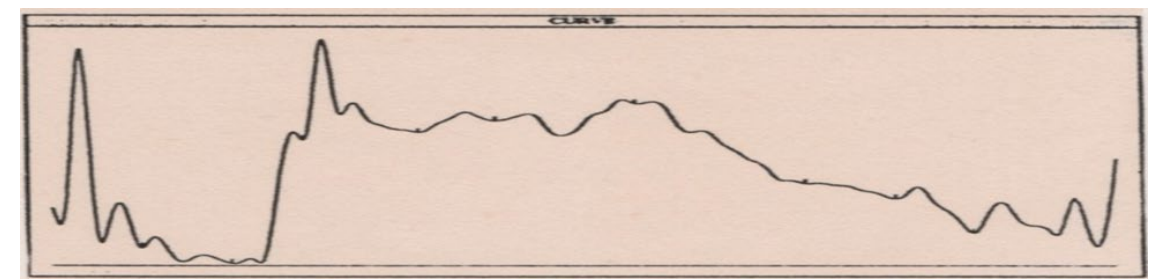

1c: Acacia auriculiformis Pretreated

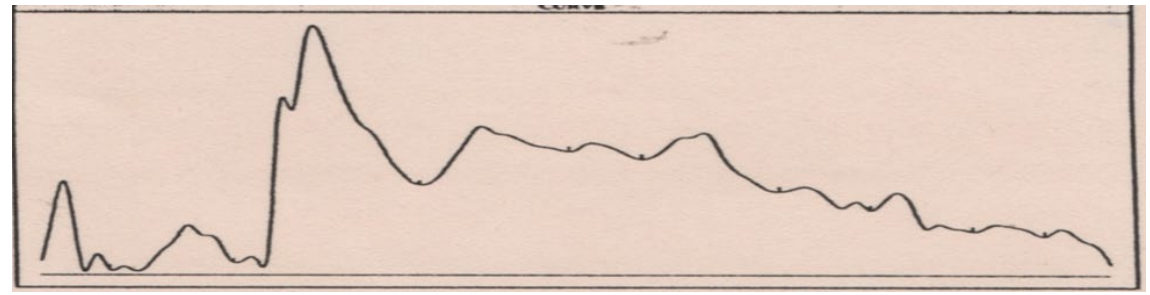

1d: Acacia auriculiformis Post-treated

Figure 1: Densitometric tracings of root proteins of okra plants resolved on acrylamide gel (SDS-PAGE). 


\subsection{ROOT PROTEINS OF THE OKRA}

Table 2: Molecular weight $(\mathrm{k})$ of the root proteins of the Acacia auriculiformis extract treatments groups of okra plants

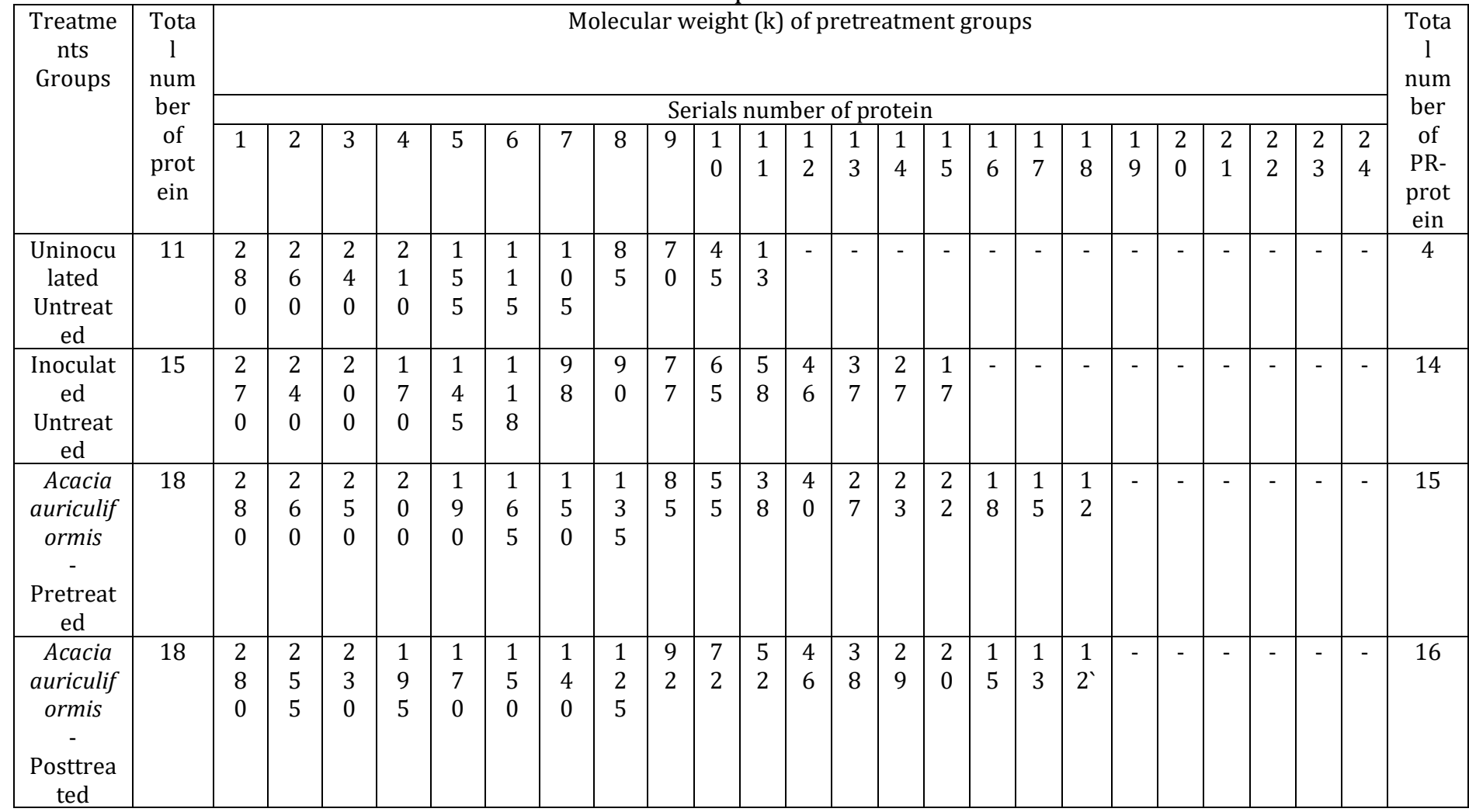

\section{6 indicate no band}

Table 2 and Fig 1; shows the molecular weight $(\mathrm{k})$ of the root proteins of the different groups of okra plants, pre- and post- treated with high diluted biomedicines; Acacia auriculiformis extract, at extremely low doses, on RootKnot disease, and Yellow Vein Mosaic Virus (YVMV) and Okra Enation Leaf Curl Virus (OELCV) foliar diseases of okra plants. An analysis of root proteins of all groups by electrophoresis and densitometer scanning of all the test plants show that all the Acacia auriculiformis extract, treatments resulted in the increased number of proteins in the roots; the lowest number of protein is 11 in the uninoculated untreated roots and highest number of proteins, are 18 in the pretreated- and post-treated- Acacia auriculiformis extract, roots respectively (Table 2 and Fig. 1). The highest molecular weight of the protein is $280 \mathrm{k}(280,000 \mathrm{kDa})$ and the lowest molecular weight of the protein is $12 \mathrm{k}$ $(12,000 \mathrm{kDa})$. The lowest number of the new pathogenesis-related protein (PR-proteins) is 4 in the uninoculated untreated roots and the highest number of the new pathogenesis-related proteins (PR-proteins) are 15 and 16, in the pretreated-and post-treated-Acacia auriculiformis extract, roots respectively (Table 2 and Fig. 1). Though, the PR-proteins of inoculated untreated is 14 (Table 2 and Fig. 1).

\subsection{SCIENCE AND TECHNOLOGY COMMUNICATIONS APPLICATIONS}

Achieved by; campaign, aware, discuss, arrange workshops and seminars, make news, and publish as abstract regarding the importance of "Pretreated- and Post-treated-Acacia auriculiformis extract, with High-Diluted, at Extremely Low Doses; Indicate the Potential Cost-Effective Biomedicines Against Various Pathogens, Including COVID-19?". 
Acacia Auriculiformis-Extract Synthesis PR-Proteins Developed Potential Biomedicines-Vaccine Against Okra-Diseases and Covid-19: Improved Science Technology Communications Bio-Economy Applications

\subsection{DEVELOPMENT OF IDEAS FOR PREPARATION OF A VACCINE}

The results may fulfill the goal for the preparation of a vaccine for the treatment of coronavirus, with the present treatments with the high-diluted biomedicines; Acacia auriculiformis-extract, at extremely low doses, against COVID19 , need to develop future research of medicines after discussion.

\subsection{FUTURE IDEAS IN RESEARCH}

Here, the results fulfill the goal of a research title because the present treatments with biomedicines; Acacia auriculiformis-extract, at extremely low doses, with regular consumption of nutritious okra-vegetables of need to justify future research ideas.

\section{DISCUSSION}

\subsection{PLANT PATHOGENS CAUSED DISEASES}

All the high-diluted biomedicines; Acacia auriculiformis extract, at extremely low doses, ones again not only reduced Root-Knot (RK) disease, and Yellow Vein Mosaic Virus (YVMV) and Okra Enation Leaf Curl Virus (OELCV) foliar diseases of okra plants but also improved the nutritive value (especially protein) of both the treated-fruits of the naturally infected plants [15], [19], [20], [21], [22], [25], [26], [27], [28], [39], [40], [41], [42], [43], [44]. It is noted that pretreated with highly-diluted Acacia auriculiformis-extract, at extremely low doses, is less effective than posttreated with highly-diluted Acacia auriculiformis-extract. So, it can be used for controlling all naturally occuring other plant diseases also.

\subsection{TOXICITY}

The present study clearly showed that the high-diluted biomedicines; pretreated- and post-treated-Acacia auriculiformis-extract, were effective or potential biomedicine at extremely low doses and it had no direct toxic effect on okra plants but to the pathogens of nematodes [31], [38], [40], [41], [42], [43], [44], [45], [46], [47], [48]. So, it may be used directly against diseases of plants and animals.

\subsection{SYNTHESIS AND DISEASE RESISTANCE MECHANISMS}

All the biomedicines; Acacia auriculiformis-extract, could induce synthesis of some antagonistic substances in the pretreated plants [14], [15], [19], [20], [21], [22], [23], [33], [48], [53], which resist against pathogens, such as lectins accumulated in gall-regions of the root of Hibiscus esculentus infected with M. incognita [64], [65], [66], [67], [68]. Systemic acquired resistance can be induced by in different crop plants by localized virus infection, nonpathogenic and pathogenic microorganisms, or their culture filtrates or by salicylic acid [69], [70], [71] or by the polar vesicle [72] or by the defense-related triterpene glycoside avenaacin A-1 is synthesized [73]. So, it can be used against diseases of plants and animals.

\subsection{DEFENSE RESPONSE ON PATHOGENESIS-RELATED (PR) PROTEINS}

It is reported that a plant plasma membrane ATP binding cassette-type transporter [74] is involved in antifungal terpenoid, for this transporter in disease resistance or by the share of common antigens with its host plants [75] or by the pure compounds of acaciasides [76], [77], [78], [79], which use against pathogens.

Treatments with the biomedicines; highly-diluted Acacia auriculiformis-extract, at extremely low doses, all the test plants synthesis of various proteins (antigens), and lowest number of the new pathogenesis-related protein (PRproteins) is 4 in the uninoculated untreated roots and highest number of the new pathogenesis-related protein (PRproteins) is 16 in the Acacia auriculiformis-extract, post-treated roots, which induce defense responses involving several pathogenesis-related proteins, specially low molecular weight proteins, in which the naturally infected plant 
Subhas Chandra Datta Ph.D.

pathogens fail to tolerate, like the NE (nematode extract) [15], [20], [21], [22], [23], [48], [80], because during natural infection with pathogen, host plant showed minimum defense responses for the antigenic (proteins) similarity [75], [81] and it is proved from the inoculated untreated pretreatment okra plants and the high-diluted drugs; Acacia auriculiformis-extract-treated roots, produce highest number of new PR-proteins, 15 and 16 respectively. So, Acacia auriculiformis-extract treatments may be used directly against diseases of plants and animals, by improving immunity or defense responses with the help of new PR-proteins [81], [82], [83], [84], [85].

\subsection{BIODIVERSITY CONSERVATIONS}

Those showed that nematode pathogens infestation somehow serves as a repressor for the expression of defense gene in plant [2], [3], [7], [8], [9], [10], [11], [12], [13], [14], [15], [16], [17], [18][19], [20], [21], [22], [28], [29], [30], [31], [33], [34], [35], [36], [37], [38], [44], [45], [47], [48], [52], [53], [54], [81], [82] and it can be assumed that the Acacia auriculiformis-extract -treated-biomedical drugs, serve as a stimulus for the expression of many new induced defense-related PR-proteins by systemic acquired resistance [65], [68], [69], [70], [81], [82], in which plant immune systems increased pathogen resistance, as well as pathogen inhibition of such defense responses [81], which is governed by defense response genes encoding for the production of various pathogenesis-related (PR) proteins [82], serving a very cost-effective eco-friendly phytomedicine and promoted growth of test plants and this highdiluted treated-biomedical drug conserved our biodiversity conservations.

Now the key question is; whether plant-derived natural products, the high-diluted Acacia auriculiformis extract-treated-biomedical drugs, at an extremely low dose, can be used as potential cost effective-biomedical by inducing defense-response against various plant-pathogens causing major (okra-) diseases in a field trial and effective against animal pathogens also? [14], [15], [19], [20], [21], [22], [23], [30], [31], [48], [80], [81], [82], [83], [84], [85].

Now the key answer; is, the high-diluted Acacia auriculiformis extract-treated-biomedical drugs, at an extremely low dose, are not only highly effective in ameliorating different plant diseases? [14], [15], [19], [20], [21], [22], [23], [30], [31], [48], [80], [81], [82], [83], [84], [85], [28], [29], [30], [31], [48], [80], [81], [82], [83], [84], [85], enriching agriculture industry as well as green biomedicine economy applications [83], [84], [85], but also may be effective against diseases of animal and human also by inducing immunity [83], [84], [85].

\subsection{DEVELOPMENT OF IDEAS FOR PREPARATION OF VACCINE}

- In Genome Biology: we're not completely human, at least when it comes to the genetic material inside our cells; 145-genes from bacteria, other unicellular organisms, and viruses with 17- as possible horizontal gene transfers [85], the genomic sequencing $96.2 \%$ identical to a bat coronavirus and shares a $79.5 \%$ sequence identity to SARS-CoV [86], [87], [88], [89] deal with the structure and function of genetic material underpinning all organisms [90], [92]. Approximately, ten percent of the human genome is made of bits of virus- DNA [90]. Human endogenous retroviruses are by far the most common virus-derived sequences in the human genome [91] which don't always require a body [92].

- In Genetic Resistance: it is reported that genetic resistance to coronavirus infection according to those three host resistance mechanisms: genetic control [16] and SARS-CoV-2 is the etiological agent responsible for the pandemic COVID-19 outbreak and the main protease (Mpro) of SARS-CoV-2 is a key enzyme that plays an important role in helping in viral replication and transcription-structure-based design of antiviral drug [93].

- In Immune System Blueprint: once the virus infects the host cell, it takes over the host cell's machinery to become a virus factory. When the human body is attacked by germs, the immune system kicks into gear to fight, by improving the immune system, creates a blueprint of the attacking agent, by which, the body effectively remembers the germ - enabling a person to fight for re-infection by the same or similar viruses [94].

- Traditional Medicine in Human History: in the evolution of human history shows the people are using traditional medicine for therapeutic purposes, and the $70 \%-80 \%$ population is primarily dependent on animals and plant-based [10], [95]. 
Acacia Auriculiformis-Extract Synthesis PR-Proteins Developed Potential Biomedicines-Vaccine Against Okra-Diseases and Covid-19: Improved Science Technology Communications Bio-Economy Applications

- Therapeutic Value of Traditional Medicines: it is reported that the biomedicine or phytomedicine-Acacia auriculiformis extract or Acaciasides (A\&B) is being used traditionally to overcome various medical complications like sore eyes, aches, rheumatism, allergy, itching, and rashes. Besides, it has also been proven for many pharmacological activities like central nervous system depressant activity, antioxidant, antimicrobial, antimalarial, antifilarial, anticestocidal, antimutagenic, chemopreventive, spermicidal, wound healing, hepatoprotective and antidiabetic activity due to its low toxicity (LD50 $=3741.7 \mathrm{mg} / \mathrm{kg}$ ) and high efficacy and the various phytochemical investigations reveal the presence of chief constituents as flavonoids and triterpenoid saponin glycosides. The low toxicity and the presence of major bioactive phytoconstituents like flavonoids and triterpenoid saponin glycosides are responsible for a therapeutic remedy for various diseases and pharmacological activities respectively. It has been used to treat several medical ailments due to its low toxicity and the presence of bioactive phytoconstituents [34]. Isolated saponins (acaciasides -A\&-B acylated triterpenoid bisglycoside) from fruits (funicles) of A. auriculiformis were screened for their antifilarial activity and results were found to be significant [96]. A US patent claimed the potential of acaciasides (A\&B) isolated from Acacia auriculiformis for the prevention of HIV infection and as a vaginal contraceptive [97]. And it has long been not only used in traditional medicine and but also as a food source for different functions [33]. Its essential oils has hepatoprotective- and hepatic non-toxic- effects, and as a natural source of hepatoprotective agent [98]. But, 4th May 2020, WHO considered as possible treatments for COVID-19 and should be tested for efficacy and adverse side effects? [98]

- Therapeutic Approach: recently, the NovavaxInc, which contributed to the development of other epidemic vaccines, has announced it is currently in pre-clinical animal trials for several multiple nanoparticle COVID19 vaccine candidates, by using their recombinant protein, the adjuvant is 'saponin-based' and it has shown a "potent and well-tolerated effect" [97], [99]. Scientists are trying to discover novel inhibitor molecules against enzymes Mpro and ACE2 by the use of phytochemicals, which be utilized for further innovation and development of antiviral compounds against Coronavirus [100].

- Vaccination: so, for successful vaccination requires four components. Human Immunomics Initiative (HII) aims to decode the underlying mechanisms and rules of how the human immune system fights disease with advances in computing and artificial intelligence, genomics, systems biology, and bioinformatics 100 . And should follow the guideline of WHO entitled "Vaccine-preventable diseases and vaccines" [10], [101], [102]. It reduces wait time for emergency vaccination [103] and one or more randomized trials will be needed to answer [104]. Then, with allopath is using trial and error method in some cases to treat COVID-19 [98], [105] and according to the World Health Organization's latest table of COVID-19 vaccines, 124-candidates with technologies or platforms. Merck's new investments focus on two different COVID-19 vaccines that are already in early clinical trials [106].

- Development of ideas for treatment: in this situation, it will be essential to inform public health expertise for moving academic research [107] with "Return to Work" [108] and a gradual, stepwise approach to reopening. And, the present results and discussion, fulfill the goal for the effective treatments methods, because the present treatments with the Acacia auriculiformis-extract, prepared from the funicles of Acacia auriculiformis, mixed with water at an extremely low dose [15], [19], [20], [21], [22], [23], [28], [39], [40], [41], [42], [43], [44], [45], [46], [47], [48] need to justify [98] for immunomodulatory effect [109].

\subsection{CAUSES FOR APPLICATIONS OF TREATMENT AGAINST COVID-19}

Recently, in lower-income countries, cause excess deaths due to closer inter-generational-contact, largely negated, and poorer health care benefit [110]. On the other hand, Yemen was grappling with "the largest humanitarian crisis in the world [111]. So, we urgently need effective drugs for coronavirus disease 2019 (Covid19), but what is the quickest way to find them? [112] For this, apply the plasma from COVID-19 survivors to help save others [114]. Recent trials, the Max Planck Institute test with plant extract [98], [114] and News Drug Target Review's therapeutics and vaccines against the novel coronavirus disease [99]. So, I think, though it is maybe applicable as a vaccine, but it will not be cost-effective and affects biodiversity in conservation with green economy applications [14], [15], [19], [20], [21], [22], [23], [30], [33]. Hence, the high-diluted biomedicines; pretreated- and post-treated-Acacia auriculiformis extract, [36], [37], [38], [44], [45], [47], [36], [37], [38], [39], [40], [41], [42], [43], 
[44], [45], [46], [47], may be used in vaccine formulations to regulate immune function by acting as -antioxidants and -scavenge oxidative stress [14], [15], [19], [20], [21], [22], [28], [29], [30], [34], [35], [115] due to the presence of chief constituents of many human health care potential biologically active chemical compounds that work through several modes of action; flavonoids and triterpenoid saponin glycosides. The low toxicity and the presence of major bioactive phytoconstituents like flavonoids and triterpenoid saponin glycosides are responsible for a therapeutic remedy for various diseases and pharmacological activities respectively. It has been used to treat several medical ailments due to its low toxicity and the presence of bioactive phytoconstituents [33], [34]. Isolated saponins (acaciasides -A\&-B acylated triterpenoid bisglycoside) from fruits (funicles) of A. auriculiformis were screened for their antifilarial activity and results were found to be significant [33], [34], [35]. A US patent claimed the potential of acaciasides (A\&B) isolated from A. auriculiformis for the prevention of HIV infection and as a vaginal contraceptive [96], [115].

\subsection{SITUATIONS FOR APPLICATIONS OF DRUGS AGAINST COVID-19}

Recently, novel coronavirus infection shows new symptom, COVID-Toes among the kids [116] and on the other hand current pandemic locust attack in India causes the new crises of food securities [117], and substantial excess deaths in lower-income countries due to the poorer health care available [110], humanitarian crisis [111], the world has joined hands to find a vaccine for the novel coronavirus. At present, many groups (80) are working globally for vaccines for humans which normally take years to develop. Currently, there are [112] potential vaccines for the SARS-CoV-2 which are in different stages of clinical trials [118]. In this situations, it is thought that the personalized medicines, may improve medical decision-making individualized diagnosis, prevention, and treatment of diseases [119], because an institute of public organization of developing countries, with the support of WHO, was an example for the production of vaccines, and to distribute free for all the population in Brazil, succeeding to be an important producer, became the "bad example" [120]. So, the present treatments with the high-diluted Acacia auriculiformisextract, biomedical drugs, at an extremely low dose, should be immediately applied against pandemic COVID-19 for beneficial clinical treatments, with no side effects [121], [122], [123], [124].

\subsection{EMERGENCY EFFECTIVE APPLICATIONS OF VACCINE}

First emergency preparations of vaccine for all patients; The high-diluted biomedicines; Acacia auriculiformis extract, prepared from the funicles of Acacia auriculiformis, @ 5-10 drops mixed with 10-20 ml of sterile distilled- or pure drinking -water, maybe orally administered twice daily in the early morning and evening respectively (before taking any food) for 10-15 days, depending on age and body weight, against naturally occurring novel coronavirus infections,15-days before symptom onset OR illness onset (as a vaccine) OR onset of symptoms where patients in hospital-associated COVID-19 infections have been reported (treatments) [31], [36], [37], [38], [39], [40], [41], [42], [43], [44], [45], [46], [47], [115], [119], [122], [124]. In the case of the application of drugs for treatment, depending on the disease intensity, the dose may be increased 3-5 times a day. It is cost-effective, ecofriendly, and easy -prepare able and -available and emergency applicable drug [33], [122], [123], [125]. It is obligatory that information on ClinicalTrials.gov, a resource provided by the U.S. National Library of Medicine (NLM), to the National Institutes of Health $(\mathrm{NIH})$ or World Health Organization or other agencies of the U.S. Federal Government, is provided by study sponsors and investigators, and they are responsible for ensuring that the studies follow all applicable laws and regulations [95], [101], [102], [116], [122], [123], [125], [126], [127], and these concerned authorities should give permission for direct-emergency [119], [120], [121], used of biomedicines; Acacia auriculiformis extract, -liquid against COVID-19 [33], [39], [44], [98], [99], [102], [103],[105], [115], [122], [123], [124], [125], which is well known with the generalized concept of medicines for emergency apply [119], [120], [121], [122], [123], and this drug serve as emergency-medicines, like antibiotics, leading to a generalized concept of medicine for emergency-applications [123], [126]. It is the most cost-effective [122], [123], easily prepare able [114], [115] easily available [20], easily applicable [119], [120], [121], [127] and help in biodiversity conservations and green economy applications against COVID-19 also [31], [33], [34], [35], [36], [37], [38], [39], [40], [41], [42], [43], [44], [45], [46], [98], [105], [115], [116], [125], for the nonspecific benefits as well as immunity to the target pathogen? [128]. 
Acacia Auriculiformis-Extract Synthesis PR-Proteins Developed Potential Biomedicines-Vaccine Against Okra-Diseases and Covid-19: Improved Science Technology Communications Bio-Economy Applications

It is known that our body as a complex system, has the capacity for self-organization, emergence and selfsimilarity over global (overall health, education, social and economic structure, and wellbeing) and local (organ) levels of organization and these features are key for future research on the systemic healing that evolves over time during individualized emergency treatment with biomedicines Acacia auriculiformis extract [129], [130], [131], [132], which is a complex nano-scale system involving multiple inter-connected, interacting components, and emergent properties [132]. So, it is the most; cost-effective, easily prepare able, easily available, and helps in biodiversity conservations and green economy applications issues and easily applicable also with increasing immunity [128] and the high-diluted biomedicines; Acacia auriculiformis extract, is the best emergency effective applicable treatment potential biomedicine [33], [39], [44], [98], [99], [102], [103],[105], [115], [122], [123], [124], [125], against COVID-19. It is also studied the cost-effectiveness of emergency care interventions in low and middleincome countries like India [120], [121], [122], [123], [124].

Second emergency preparations of vaccine for general and nondiabetic patients; The high-diluted Acacia auriculiformis extract, -globules, prepared from the few drops of a liquid Acacia auriculiformis extract, by pouring and to just moistening all the sucrose-globules in the vial forming Acacia auriculiformis extract, -biomedicinesglobules [31], [36], [37], [38], [39], [40], [42], [43], [44], [45], [46], [47], [115], [119], [122], [123], [124], @ 10-20 medicated-globules (7.2-14.4mg), maybe orally administered thrice daily in the early morning, afternoon and evening (before taking any kinds of food) for 10-15 days, depending on age and body weight, against naturally occurring virus infections 15-days before symptom onset OR illness onset (as a vaccine) OR onset of symptoms where patients admitted in hospital with COVID-19 infections have been reported (treatments) [123]. In the case of treatment, depending on the disease intensity, the dose may also be increased 3-4 times a day. It is also the most cost-effective and easy -prepare able, -available, and easy-applicable drug [122], [123], [124], [125]. The biomedicine Acacia auriculiformis-extract, -globules can also be directly used for emergency effective treatment of COVID-19 after getting permission from the; -WHO, -ClinicalTrials.gov., -U.S. NLM and -NIH [95], [101], [102], [116], [122], [123], [125], [126], and the concerned authorities, should give permission for direct-emergency used of biomedicines Acacia auriculiformis-extract,-globules against COVID-19, because for no side effects [33], [115], [119], [122], [124], [125], and serve also as antibiotics, leading to a generalized concept of medicine [123], [126], [127], [128], [129], [130], [131], future research on the systemic healing that evolves over time during individualized emergency applications [131], with multiple interconnected, interacting components, and emergent properties [132]. It is the most; cost-effective, easily prepare able, easily available, and helps in biodiversity conservations and green economy applications issues and easily emergency-applicable also with increasing immunity [128] and it is the best emergency effective applicable treatment methods [33], [39], [44], [98], [99], [102], [103],[105], [115], [122], [123], [124], [125], against COVID-19, without spending time and it also becomes the most cost-effectiveness of emergency applicable-care interventions in low and middle-income countries like India [120], [121], [122], [123], [124], [125].

Third emergency preparations of vaccine for all patients; The adjuvant Acacia auriculiformis extract, [33], [98], [114], [115], may be used with recombinant protein nanoparticle antigens derived from the coronavirus spike protein and combine these antigens with its adjuvant Acacia auriculiformis-extract for the final formulation of the vaccine and it may be shown a "potent and well-tolerated effect" through stimulating the entry of antigen-presenting cells into the injection site and enhancing antigen presentation in local lymph nodes, boosting immune responses [31], [36], [37], [38], [39], [40], [42], [43], [44], [45], [46], [47], [97], [98], [99], [113], [114], [115], [133]. In a letter as an e-mail, the Science Advisory Board Net, at Express Cells, for their business of creating better knock-in cell lines for drug discovery, toxicology, and other biologic research and add for purchase SARS-CoV-2 Spike Protein (NC_045512.2), SARS-CoV-2 Nucleocapsid Protein (NC_045512.2), TMPRSS2 (NM_001135099.1), ACE2 (NM_021804.3), BSG (CD147) (NM_001728.3), SARS-CoV Nucleocapsid Protein (MK062179.1), SARS-CoV Spike Protein (MK062179.1), MERS-CoV Nucleocapsid Protein (NC_019843.3), MERS-CoV Spike Protein (NC_019843.3) [133] and the readily available coronavirus spike proteins may be helped to use for vaccine preparation which may fight against "COVID Toes among kids: New symptom of novel coronavirus infection" [116]. Here, vaccination or treatments, is the use of remedies against diseases either earlier in an epidemic or given routinely to prevent diseases. When the latter is used it involves mostly the users just like any conventional vaccination which administers the antigen in an inactive state to gain immunity towards the disease and is given before the onset of 
Subhas Chandra Datta Ph.D.

disease or disease symptoms in an individual as a prevention rather than cure [122] and in a clinical study shows the efficiency of triple antibiotic mixture and propolis as intracanal medication in revascularization process in immature apex [122], [134]. It is obligatory that information to the ClinicalTrials.gov, the U.S. National Library of Medicine, to the National Institutes of Health or other agencies of the U.S. Federal Government [95], [101], [102], [116], [122], [123], [125], [126], [127], and maybe easily emergency-applicable drugs with increasing immunity [128].

Fourth emergency preparations of vaccine for all patients; The adjuvant Acacia auriculiformis extract, [33], [39], [98], [114], [115] maybe used with anti-Human antibodies like IgG (A80-104A, A80-105A), IgM (A80-100A, A80-101A), \& IgA (A80-102A, A80-103A) and offer treatments or vaccine preparation of COVID-19 (SARS-CoV-2) and it may also be accelerated the discovery to improve lives [33], [101], [115], [116], [122], [126], [127], [133], [134], [135], [136]. After getting successful clinical trials, the concerned authorities may be permitted for the use as a vaccine for emergency preparation for treatments against novel coronavirus [95], [101], [102], [116], [122], [123], [125], [126], [127].

Note for emergency applications; Recently, the NovavaxInc, has announced it is currently in pre-clinical animal trials for several multiple nanoparticle COVID-19 vaccine candidates, the adjuvant is 'saponin-based' [33], [97], [98], [99], [115]. Merck's new investments focus on two different COVID-19 vaccines that are already in early clinical trials [33], [106], [115] and the Max Planck Institute test plant extract [98], [114] against the novel coronavirus disease with little toxicity and artemisinin-based saponin-content drugs are widely used to treat malaria even in newborns [102], [106], [114]. In this pandemic situations, it is thought that the high-diluted biomedicines (liquid and globules); Acacia auriculiformis-extract, at the above-mentioned doses, the personalized medicines, may improve medical decision-making individualized diagnosis, prevention, and emergency applicable cost-effective treatments against COVID-19 diseases [119], with the support of WHO, NIH, ClinicalTrials.gov. and U.S. NLM, showing an example for the 'Use, Production and Emergency Application of Vaccines', and to distribute free for all the population [95], [101], [102], [116], [122], [123], [125], [126], [127]. Because, all the high-diluted Acacia auriculiformis-extract, -liquid and -globules biomedicines, are making them capable for different biological activities and expected to be effective against Covid-19, and the U.S. Centers for Disease Control and Prevention (CDC) and the World Health Organization (WHO), want to apply safe vaccine against SARS-CoV-2, for the newly developed-late hyperinflammatory multisystem inflammatory syndrome in children (MIS-C) and adults with Covid-19 [33], [115], [136], [137]?

Science and Technology Communications Biomedicines Applications; Recently, the Coronavirus pandemic has adverse effects on education, especially on school education and characteristics, including research, academic programs, staff professional development, and jobs also [129]. At present, many groups (80) are working globally for vaccines for a human which normally takes years to develop. Currently, there are [112] potential vaccines for the SARS-CoV-2 which are in different stages of clinical trials [118] and a committee that makes vaccine use recommendations to the U.S. Centers for Disease Control and Prevention (CDC), suggesting they should be high on the list [138]. Because, the behavioral scientists provide a road-map for the public to manage the trauma of COVID19 and its aftermath successfully, learned from biomedical science [139], and gird for a war on vaccine misinformation [140].

While a cure or vaccine for COVID-19 is not available, in the absence of any side-effects and adverse interactions with any conventional medicines along with a robust safety profile and repeated evidence-based successes against viral infections, the high-diluted biomedicine (liquid and globules); Acacia auriculiformis extract, at an extremely low dose, may play an important role in the fight against COVID-19 [122], [123], [124]. It is the most; cost-effectivemethods, easily prepare able, easily available, and help in biodiversity conservations and green economy applications issues also [31], [33], [34], [35], [36], [37], [38], [39], [40], [41], [42], [43], [44], [45], [46], [98], [105], [115], [116], [125] and should be use as emergency applicable methods against COVID-19 as early as possible [105], [119], [120], [121], [122], [123], [124], [125], [126], [127], [128], [129] for taking measures or treatment opportunities or avoid new coronavirus infections. And immediate apply by; campaign, aware, discuss, arrange workshops and seminars, make news, and publish as abstract regarding the importance of "The Biomedicines (liquid and globules) Acacia auriculiformis extract, at extremely low doses; Indicate the Potential Cost-Effective Biomedicines Against Various Pathogens including COVID-19 by Improving Immunity".

International Journal of Research -GRANTHAALAYAH 

and Covid-19: Improved Science Technology Communications Bio-Economy Applications

Future Ideas in Research Vaccine; Here, the results fulfill the goal of a research title because the present treatments with biomedicines; Acacia auriculiformis-extract, at extremely low doses, with regular consumption of okra vegetables of need to justify future research ideas. It is known that social vaccines resist and change unhealthy social and economic structures and useful metaphor for health promotion [130]. Okra plants itself may serve as a good "Eco-Friendly Highly Economical Plants as well as Biomedicines" thereby reducing diseases conserving our biodiversity contributing towards "Sustainable Climate Health and Development" and it may have important economic implications in agriculture to fulfill its food and nutrition requirement and improved midday meals by preventing malnutrition. And highly-trace-tolerance-okra may be used, in vaccine formulations or treatments or social vaccine, as one of the most powerful potential-biomedicine, improving natural immunity against COVID-19, enriching science and technology communication applications food security economy. It may be the most; costeffective, easily-available, safe-edible and prepare able as well as and safe alternative to live replicating COVID-19 social vaccines which restarts, a window of hope and opportunity open for nations to green their recovery the 21stcentury economy in ways that are clean, green, healthy, safe and more resilient, and a large number of people may be immune or resistant to SARS-COV-2 due to they have already been infected by other coronaviruses [141], [142], [143], [144], [145], [146] and Emergency Use Authorization of Covid Vaccines -

Safety and Efficacy Follow-up Considerations [146]. And Okra maybe use as future biomedicine improved immunity against COVID-19 enriching science and technology communication applications food security economy [142], [146].

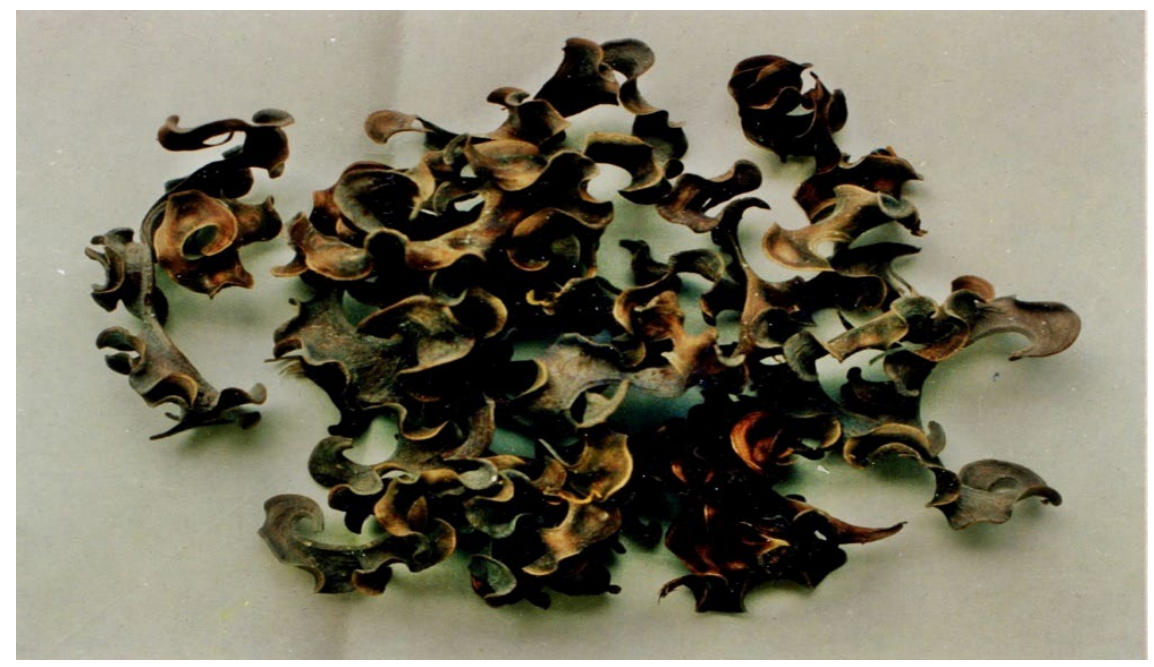

Plate 1: Funicles of Acacia auriculiformis A. Cunn.

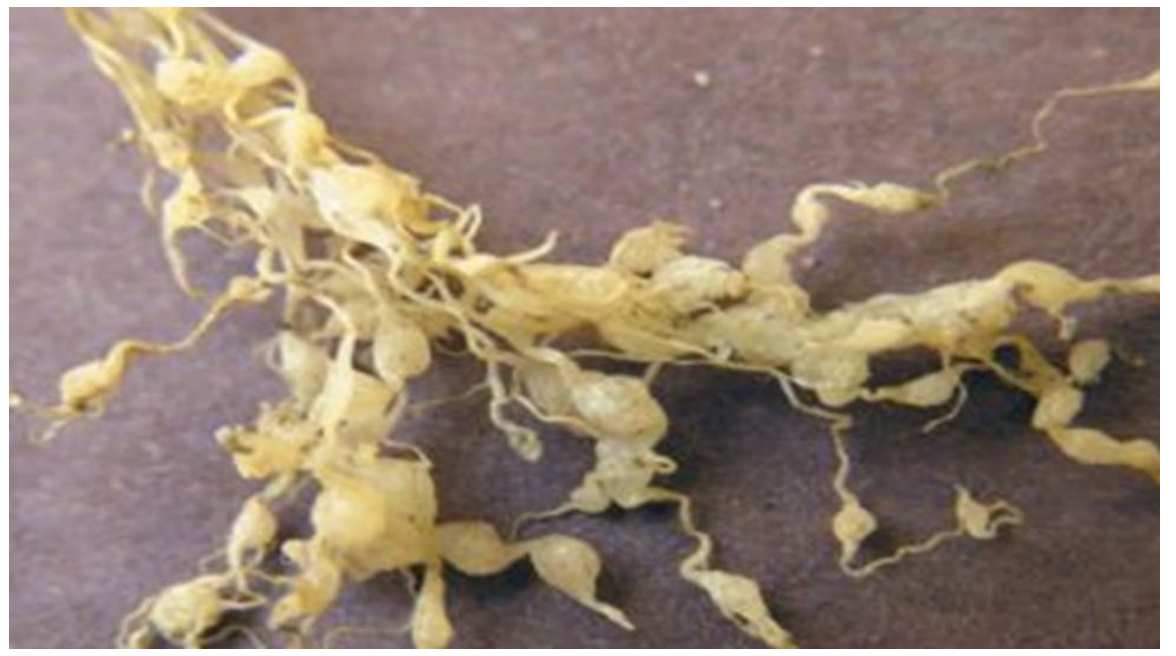

Plate 2: Root-Knot (RE) disease caused by Meloidogyne incognita of okra 


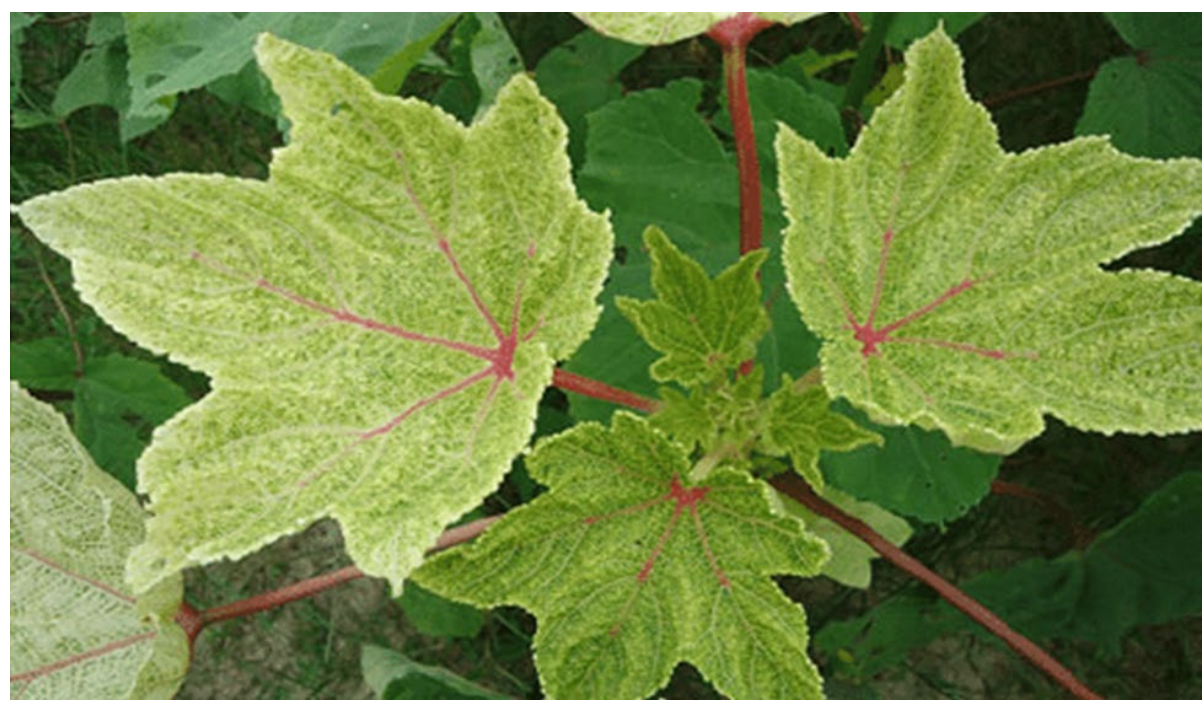

Plate 3: Yellow Vein Mosaic Virus (YVMV) disease of okra

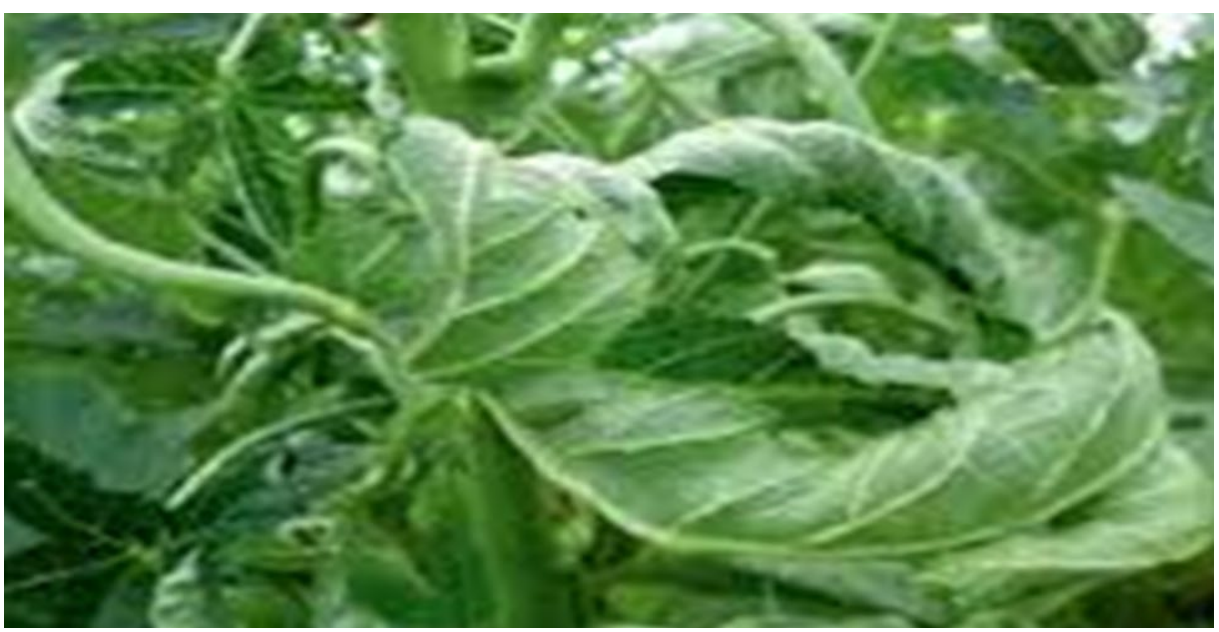

Plate 4: Okra Enation Leaf Curl Virus (OELCV) disease of okra

\section{CONCLUSIONS}

The biomedicines- Acacia auriculiformis-extract, at extremely low doses, not only used as a potentialbiomedical-drugs or vaccine against various plant-diseases, by synthesis of new PR-proteins, increasing naturaldefense-response, but also, it may be increased urgency to prepare safe and an effective emergency use for treatment for prevention coronavirus, the COVID-19, by increasing the immune system for the improvement of biomedicines economy applications science and technology communication cost-effectiveness and biodiversity conservations as well as bio-applications issues, reviving human civilizations in the old form. And in near future okra may itself be a 'Vaccine as well as Biomedicine', and safe alternative to live replicating COVID-19 vaccines which restarts, a window of hope and opportunity open for nations to green their recovery the 21st-century economy in ways that are clean, green, healthy, safe and more resilient.

\section{SOURCES OF FUNDING}

This research received no specific grant from any funding agency in the public, commercial, or not-for-profit sectors. 
Acacia Auriculiformis-Extract Synthesis PR-Proteins Developed Potential Biomedicines-Vaccine Against Okra-Diseases and Covid-19: Improved Science Technology Communications Bio-Economy Applications

\section{CONFLICT OF INTEREST}

The author have declared that no competing interests exist.

\section{ACKNOWLEDGMENT}

The work has been supported by Prof. N.C. Sukul, Prof. S.P. Sinha Babu, and all the researchers of Biochemistry Laboratory, Department of Zoology, Visva-Bharati. I am thankful to the eminent Senior Consultant Physician \& Cardiologist Dr. Tushar Kanti Batabyal, M.B.B.S., M.D., Ex-Clinical Tutor of the Burdwan Medical College \& Hospital, for inspiration and guidance. I express my deep gratitude to Mr. Rakesh Khan, Secretary and Mr. Subhendu Bose, President with all Young Green-Members of the 'International NGO named Burdwan Green Haunter and Students' Goal" for arranging to many awareness programmed on a social vaccine against COVID-19. Last but not the least; I am thankful to the eminent educationist Sri Tapaprakash Bhattacharya for inspiration and guidance.

\section{REFERENCES}

[1] Filetti S (2020) The COVID-19 pandemic requires a unified global response. Springer Science Business Media, LLC, part of Springer Nature, Endocrine 2020. https://doi.org/10.1007/s12020-020-02293-6.

[2] Brouwer PJM, Caniels TG, Straten KVD, Snitselaa JL, Aldon Y, et al. (2020) Potent neutralizing antibodies from COVID-19 patients define multiple targets of vulnerability. Science. ScienceMag.org, First Release 15 Jun 2020:1-14. doi: 10.1126/science.abc5902 (2-020).

[3] Chen Y, Liu Q, Guo D (2020) Emerging coronaviruses: Genome structure, replication, and pathogenesis. J Med Virol 92:418-423. https://doi.org/10.1002/jmv.25681.

[4] Science Daily (2020) The genetic quest to understand COVID-19: Unlocking the genetic code of the novel coronavirus will help us prevent other diseases. ScienceDaily, Science News, 26 March 2020, University of Sydney.

[5] Zhang YZ, Holmes EC. A Genomic Perspective on the Origin and Emergence of SARS-CoV-2. Cell 2020. doi: 10.1016/j.cell.2020.03.035.

[6] Buschman E, Skamene E (2019) Genetic Resistance to Coronavirus Infection- A Review. Part of the Advances in Experimental Medicine and Biology book series (AEMB, volume 380), Springer Nature Switzerland AG. Part of Springer Nature. Corona- and Related Viruses 2019;1-11.

[7] Roujian L, Xiang Z, Juan L, Peihua N, Bo Y, Honglong W, et al. (2020) Genomic characterization and epidemiology of 2019 novel coronavirus: implications for virus origins and receptor binding. February 22, 2020, 395: 565-574.

[8] Julka A (2020) Coronavirus India News Live Updates 24 April 2020: COVID-19 Cases Soar Past 24000. Grain Mart News, April 24, 2020.

[9] Cohen J (2020) United States should allow volunteers to be infected with coronavirus to test vaccines, lawmakers argue. Science, Posted in: Health Science and Policy Coronavirus. Apr. 21, 2020, 11:55 AM. doi:10.1126/science.abc3772.

[10] World Health Organization. (2020) Coronavirus disease (COVID-2019) An international randomized trial of candidate vaccines against COVID-19 version. World Health Organization's, R\&D Blueprint 19 April 2020. https://www.who.int/blueprint/priority-diseases/key-action/novel-coronavirus/en/.

[11] Kochlar SI (1986) Okra (lady finger) in tropical crops, a text book of economic botany 1: 263-264.

[12] Kumar DS, Tony DE, Kumar AP, Kumar KA, Rao DBS, Nadendla R (2013) A REVIEW ON: ABELMOSCHUS ESCULENTUS (OKRA). Int. Res J Pharm. App Sci 3(4):129-132.

[13] Anonymous. (2015) Indian Horticulture Database. National Horticulture Board, Ministry of Agriculture, Government of India, Gurgaon.

[14] Datta SC (2005a) Plant parasitic nematodes - an agricultural problem and its solutions. The Visva Bharati Quarterly 11:89-100.

[15] Datta SC (1999) Bio-nematicides in the control of root-knot nematode. Ph.D. thesis, Department of Zoology, Visva Bharati, Santiniketan-731235, West Bengal, India (unpublished). 
[16] Jatav PKJ, Singh K, Mathapati G, Gowda R, Karoriya S, Nalla MK (2018) Breeding for Virus Resistance in Okra. Int.J.Curr.Microbiol.App.Sci.7(08):3053-3065. doi: https://doi.org/10.20546/ijcmas.2018.708.325.

[17] Valipour M (2014) Handbook of water engineering problems. Foster City (CA): OMICS Group eBooks 2014. http://www.esciencecentral.org/ebooks/handbook-of-water-engineering-problems/pdf/handbook-ofwater-engineering-problems.pdf.

[18] Valipour M (2015) What is the tendency to cultivate plants for designing cropping intensity in irrigated area? Adv in Water Sci and Tech 10:01-12.

[19] Datta SC, Sinhababu SP, Sukul NC (1997) Improved growth of silkworms from effective treatment of mulberry diseases by Acacia auriculiformis extract. Sericologia 37:707-715.

[20] Datta SC (2020a) Enriched Science and Technology Communication Economy in Agriculture by Use of Acacia sides as Potential Bio-Agents against Various Pathogens. Advances in Agriculture, Horticulture and Entomology 2:1-13.

[21] Datta SC, Datta R (2016) Prevention and control of root-knot disease of mulberry plants using bioagents amaranth plants: improving sericulture by protecting climate health, health and development. Journal of Environment \& Sociobiology 13:191-200.

[22] Datta SC, Datta R, Sinhababu SP, Sukul NC (1998) Acaciasides and root-knot nematode extract suppress Melodogyne incognita infection in lady's finger plants. Proceeding of the National Seminar on Environmental Biology 98:205-209.

[23] Datta SC, Sinhababu SP, Banerjee N, Ghosh K, Sukul NC (1998) Melodogyne incognita extract reduces Melodogyne incognita infestation in tomato. Indian J Nematol 28:1-5.

[24] Datta SC, Datta R, Sukul A, Sukul NC, Sinhababu SP (2000) Relative attractiveness of four species of vegetable crops for Meloidogyne incognita. Environ Ecol 18:233-235.

[25] Datta SC (2006b) Possible use of amaranth as catch crop for root-knot nematodes intercropped with okra. Phytomorphology 56:113-116.

[26] Datta SC, Datta R (2007b) Intercropping amaranth with mulberry for managing root-knot nematodes and improving sericulture. Sericologia 47(3):297-302.

[27] Datta SC (2019a) Improved Environment by Identification of More Susceptible Plant Between Cowpea and Mulberry for Root-Knot Disease. Open Access Journal of Environmental Soil Science 2(5):242-245. doi: 10.32474/OAJESS.2019.02.000148.

[28] Datta SC, Datta R (2007a) Increased silk production by effective treatment of naturally infected root-knot and black leaf spot diseases of mulberry with Acaciasides. Journal of Environmental \& Sociobiology 4:209-214.

[29] Datta SC (2007) Mulberry disease: Problem in sericulture. SEBA NEWSLETTER, Environment \& Sociobiology 4:7-10.

[30] Datta SC, Datta R (2012c) Efficacy of pure compound- acaciasides A and B as potential bioagents against various plant pathogens. Journal of Environment \& Sociobiology 9(1):17-26.

[31] Sukul NC, Sinhababu SP, Datta SC, Nandi B, Sukul A (2001) Nematotoxic effect of Acacia auriculiformis and Artemisia nilagirica against root-knot nematodes. Allelopathy Journal 8:65-72.

[32] Datta SC (2019e) Improved midday meal by using cowpea as eco-friendly crop controlling root-knot forming global, green, growth and green economy. International Journal of Advanced Research (Accepted).

[33] Datta SC (2020b) Discovery of COVID-19 Vaccine by Using Acaciades as a Phytomedicine Improving Science and Technology Communication Applications- An Ideas. Open Access Journal of Biogeneric Science and Research 2(1):1-30. doi:10.46718/JBGSR.2020.01.000032.

[34] Rangra NK, Samanta S, Pradhan KK (2019) A comprehensive review on phytopharmacological investigations of Acacia auriculiformis A.Cunn. ex Benth. Asian Pacific Journal of Tropical Biomedicine 9(1): 1-11. doi: 10.4103/2221-1691.250263.

[35] Mahato SB (1996) Saponins with antifilarial activity from Acacia auriculiformis. In: Waller GR, Yamasaki K (eds). Saponins used in traditional and modern medicine. New York, USA: Springer, 1996:173-184.

[36] Datta SC, Datta R (2011b) Homeopathic Medicines Protect Environment, Health and Development by Controlling Mulberry Diseases. JJ Homeop Ayurv Med 1:104. doi:10.4172/2167-1206.1000104.

[37] Datta SC, Datta R (2012a) Homeopathic Medicines Protect Environment, Health and Development by Controlling Mulberry Diseases. Journal of Traditional Medicine \& Clinical Naturopathy 1:104.

[38] Datta SC (2019b) Enriched Sericulture from Effective Treatment of Mulberry Diseases by Homeopathic Medicines. Adv Biochem Biotechnol 7:084. doi: 10.29011/2574-7258.000084. 
Acacia Auriculiformis-Extract Synthesis PR-Proteins Developed Potential Biomedicines-Vaccine Against Okra-Diseases and Covid-19: Improved Science Technology Communications Bio-Economy Applications

[39] Sukul NC, Sukul A (2005) High Dilution Effects: Physical and Biochemical Basis. Authors Nirmal C. Sukul, Anirban Sukul Copyright 2005 Publisher Springer Netherlands Copyright Holder, Springer Science \& Business Media B.V. eBook Edition Number 1Number of Pages XII, 2005;130. doi: 10.1007/1-4020-2156-9.

[40] Datta SC (2006a) Effects of Cina on root-knot disease of mulberry. Homeopathy 95:98-102.

[41] Datta SC, Datta R (2006) Liquid homeopathic medicine Cina enriches sericulture industry. Journal of Environmental \& Sociobiology 3:55-60.

[42] Datta SC, Datta R (2008) Potentized Artemisia nilagirica extract Cina increases silk production and effective rate of rearing in a field trial. Hpathy Ezine.

[43] Datta SC (2010) The Role of Cina in the Field of Enriched Sericulture. Hpathy Ezine.

[44] Anonymous. (1920) The American Homeopathic Pharmacopoeia. 9th edn, Philadelphia, USA: Boericke and Tafel.

[45] Datta SC, Datta R (2011b) Control of Root-Knot Disease of Mulberry by Homeopathic Medicines: Aakashmoni [Mt, 30c, 200c \& 1000c] Prepared from the Funicles of Acacia Auriculiformis. Hpathy Ezine.

[46] Datta SC, Datta R (2012b) Homeopathic medicine Aakashmoni 200C control mulberry diseases enriching sericulture. Journal of Current Chemistry Pharmacological Science 2: 37-49.

[47] Datta SC, Datta R (2013) Efficacy of homeopathic medicine-Aakashmoni as potential bio-agent against various plant pathogens. Journal of Biochemistry \& Pharmacology 2: 4. http://dx.doi.org/10.4172/21670501.S1.004.

[48] Datta SC, Datta R (2000) Defence resistance of okra against root-knot disease by bio-nematicides. Proceedings of the Zoological Society,Calcuutta University,Calcutta, West Bengal 59(2):75-82.

[49] Fenner LM (1962) Determination of nematode mortality. Plant Disease Reporter 46:383.

[50] Christie JR, Perry VG (1951) Removing nematodes from soil. Proceeding of Helminthological Society, Washington 18:106-108.

[51] James WC (1971) An illustrated series of assessment keys for plant diseases, their preparation and usage. Can Plant Disease Surv 51:39-65.

[52] Sukul NC (1987) Soil and plant nematodes. West Bengal State Book Board Publisher pp. 1-271.

[53] Zhan Y, Wu Q, Chen Y, Tang M, Sun C, Sun J, Yu C (2019) Comparative proteomic analysis of okra (Abelmoschus esculentus L.) seedlings under salt stress. BMC Genomics 20:381. https://doi.org/10.1186/s12864-0195737-7.

[54] Govindaiah, Sharma DD (1994) Root-knot nematode, Meloidogyne incognita infesting mulberry - a review. Indian Journal of Sericulture 33:110-113.

[55] Hussey RS, Barker KR (1973) A comparison of methods of collecting inocula of Meloidogyne spp., including a new technique, Plant Disease Reporter 57:1025-1028.

[56] Lowry OH, Rosebrough NJ, Farr AL, Randall RJ (1951) Protein measurement with the Folin-Phenol reagent. J Biol Chem 193: 265-275.

[57] Chatterjee A, Sukul NC (1981) Total protein of galled roots as an index of root-knot nematode infestation of lady finger plants. Phytopathol 71: 372-274.

[58] Sukul NC (1992) Plants antagonistic to plant parasitic nematodes. Indian Review of Life Science 12:23-52.

[59] Laemmli U K (1970) Cleavage of structural proteins during the assembly of the head of bacteriophage T4. Nature 227: 680-685.

[60] Mouemar AAL, Gasquez J (1983) Environmental conditions and isozyme polymorphism in Chenopodium albumL. Weed Research 23:241-249.

[61] Datta SC (2019c) Enriched School Health for The Effective Healthcare Bio-Activity of Barn Owls. Research \& Review of Health Care Open Access Journal 3(3):269-275. doi: 10.32474.

[62] Datta SC (2019d) Enriched School Environment for the Effective Bio-Activity of Barn Owls. International journal of Horticulture, Agriculture and Food science (IJHAF) 3(3):119-126. https://dx.doi.org/10.22161/ijhaf.3.3.2.

[63] Datta SC (2020c) Improved Science and Technology Communications: Barn Owl Act as Social Vaccine Against COVID-19. International Journal of Latest Research in Science and Technology 9(3):6-13. https://www.mnkjournals.com/journal/ijlrst/Article.php?paper_id=10994.

[64] Das S, Sukul NC, Mitra D, Sarkar H (1989) Distribution of lectin in nematode infested and uninfested roots of Hibiscus esculentus. Nematologica Mediterranea 17:123-125. 
[65] Klessig, Daniel F, Malamy J (1994) The salicylic acid signal in plants. Plant Molecular Biology 26:1439-1458.

[66] Field B, Jordan F, Osbourn A (2006) First encounters - development of defence - related natural products by plants. New Phytologist 172:193-207.

[67] Sukul NC (1994) Control of plant parasitic nematodes by plant substances. Allelopathy in Agriculture and Forestry, (Edited by S.S. Narwal and P. Tauro), Scientific Publisher, Jodhpur, India 183-211.

[68] Mauch-Mani B, Metraux JP (1998) Salicylic acid and systemic acquired resistance to pathogen attack. Annals of Botany 82:535-540.

[69] Nandi B, Kundu K, Banerjee N, Sinhababu SP (2003) Salicylic acid -induced suppression of Meloidogyne incognita infestation of okra and cowpea. Nematology 5:747-752.\

[70] Ross AF (1961) Systemic acquired resistance induced by localized virus infection in plants. Virology 14: 340358.

[71] Osbourn AE, Clarke BR, Lunness P, Scott PR, Daniels MJ (1994) An oat species lacking avenacin is susceptible to infection by Gaeumannomyces graminis var. tritici. Physiological and Molecular Plant Pathology 45:457467.

[72] Jasinski M, Stukkens Y, Degand H, Purnelle B, Marchand-Brynaert J, Boutry M (2001) A plant plasma membrane ATP binding cassette-type transporter is involved in antifungal terpenoid secretion. Plant Cell 13:1095-1107.

[73] Stukkens Y, Bultreys A, Grec S, Trombik T, Vanham D, Boutry M (2005) NpPDRI, a pleiotropic drug resistancetype ATP-binding cassette transporter from Nicotiana plumbaginifolia, plays a major role in plant pathogen defense. Plant Physiology 139:341-352.

[74] McClure MA, Misaghi I, Night Edward LJ (1973) Shared antigens of parasitic Nematodes and Host plants. Nature 244:306.

[75] Osbourn AE (1996) Saponins and plant defence- a soap story. Trends in Plant Science 1:4-9.

[76] Papadopoulou K, Melton RE, Leggett M, Daniels MJ, Osbourn AE (1999) Compromised disease resistance in saponin-deficient plants. Proceedings of the National Academy of Science, USA 96:12923-12928.

[77] Osbourn AE, Qi X, Townsend B, Qin B. Secondary metabolism and plant defence. New Phytologist 2003; 159:101-108.

[78] Sasser JN, Freckman DW (1986) Proceedings of 25th Annual Meeting Society of Nematologists, Orlando, Florida 86:32.

[79] Zarter CR, Demmig-Adams B, Ebbert V, Adamska I, Adams WW III (2006) Photosynthetic capacity and light harvesting efficiency during the winter-to-spring transition in subalpine conifers. New Phytologist 172:283292.

[80] Andersen EJ, Ali S, Byamukama E, Yen Y, Nepal MP (2018) Disease Resistance Mechanisms in Plants. Genes 9:339. doi:10.3390/genes9070339.

[81] Prasannath K (2017) Plant defense-related enzymes against pathogens: A Review. Plant defence-related enzymes 38-48. doi: http://doi.org/10.4038/agrieast.v11i1.33.

[82] Harikrishnan R, Balasundaram C, Heo MS (2011) Impact of plant products on innate and adaptive immune system of cultured finfish and shellfish. Aquaculture 317:1-15. doi: 10.1016/j.aquaculture.2011.03.039.

[83] Smith KG, Kamdar AA, Stark JM (2019) Lung Defenses: Intrinsic, Innate, and Adaptive. Kendig's Disorders of the Respiratory Tract in Children (Ninth Edition) e2:120-133. https://doi.org/10.1016/B978-0-323-448871.00008-0.

[84] Williams SCP (2015) Humans may harbor more than 100 genes from other organisms. Science, Posted in: Biology 2015. doi:10.1126/science. aab0307.

[85] Zhou P, et al. (2020) A pneumonia outbreak associated with a new coronavirus of probable bat origin. Nature Medline 2020;579:270-273. doi:10.1038/s41586-020-2012-7.

[86] Wu F, et al. (2020) A new coronavirus associated with human respiratory disease in China. Nature Medline 579:265-269. doi:10.1038/s41586-020-2008-3.

[87] Lu R, et al. (2020) Genomic characterisation and epidemiology of 2019 novel coronavirus: Implications for virus origins and receptor binding. Lancet Medline 395:565-574. doi:10.1016/S0140-6736(20)30251-8.

[88] Appels R, Nystrom J, Webster H, Keeble-Gagnere G (2015) Discoveries and advances in plant and animal genomics. Funct Integr Genomics15:121-129. doi:10.1007/s10142-015-0434-3.

[89] Science Daily (2016) Our complicated relationship with viruses. Science News NIH, National Institute of General Medical Sciences (NIGMS) 2016. 
Acacia Auriculiformis-Extract Synthesis PR-Proteins Developed Potential Biomedicines-Vaccine Against Okra-Diseases and Covid-19: Improved Science Technology Communications Bio-Economy Applications

[90] On Biology (2019) The viral content of human genomes is more variable than we thought. Rebecca Pearce, Journal Development Manager at BMC, Blog Network 2019.

[91] Callif BL (2020) The Human Genome Is Full of Viruses. Medium, Medical Myths and Models.

[92] Zhang LK, et al. (2020) Structure-based design of antiviral drug candidates targeting the SARS-CoV-2 main protease. Cite as: W. Dai et al., Science 2020;10.1126/science.abb4489. http://science.sciencemag.org/content/early/2020/04/21/science.abb4489.

[93] Speiser J (2020) The COVID-19 Disease and Our Genes. Ken Burns, A special post from guest writer Joshua Speiser, The Gene 7th April, 2020.

[94] IUCN. (1993) Guidelines on the conservation of medicinal plants. The International Union for Conservation of Nature and Natural Resources, World Health Organization and World-Wide Fund for Nature. Gland, Switzerland1993.

[95] Kabir SN, Ray HN, Pal BC, Mitra D (2014) Pharmaceutical composition having virucidal and spermicidal activity. US8729034 (Patent) 2014.

[96] Said N (2020) Coronavirus COVID-19: Available Free Literature Provided by Various Companies, Journals and Organizations around the World. Ongoing Chemical Research 5(1):7-13. doi:10.5281/zenodo.3722904.

[97] Times of India. (2020) Covid-19: WHO cautions against untested traditional remedies. The World Health Organization (WHO), Paris, 4th May 2020.

[98] News Drug Target Review's. (2020) Coronavirus update: recent developments in vaccine Research. Drug Target Review's round-up of the latest developments in 2019 novel coronavirus (COVID-19 or SARS-CoV-2) therapeutics and vaccines 27th February 2020.

[99] Joshi T, Joshi T, Sharma P, Mathpal S, Pundir H, Bhatt V, Chandra S (2020) In silico screening of natural compounds against COVID-19 by targeting Mpro and ACE2 using molecular docking. European Review for Medical and Pharmacological Sciences 24:4529-4536.

[100] Sweeney C (2020) Human Immunomics Initiative will decode immune system, speed new vaccines. Harvard T.H. Chan School of Public Health News, April 14, 2020, Copyright (C) 2020 The President and Fellows of Harvard College csweeney@hsph.harvard.edu, 617.549.2638. https://www.hsph.harvard.edu.

[101] WHO. (2020) Vaccine-preventable diseases and vaccines. International travel and health Chapter 6:1-61, See country list updated yearly on WHO's ITH web page at: http://www.who.int /ith/en/ http://www.who.int/immunization_standards/vaccine_quality/PQ_vaccine_list_en/en/

[102] Bougrine R, Hdidou Y, Aissaoui H, Elouafi N, Ismaili N (2019) Emergency stay triggered Tako-Tsubo syndrome: A case report and review of the literature. Glob J Medical Clin Case Rep 6(2):035-038. https://dx.doi.org/10.17352/2455-5282.000077.

[103] Soler MJ, Barrios C, Oliva R, Batlle D (2008) Pharmacologic modulation of ACE2 expression. Curr Hypertens $10: 410-4$.

[104] The Times of India. (2020) Homeopathy, ayurveda docs want a chance to treat Covid-19. RANCHI: TOI, TNN, May 11, 2020.

[105] Merck JCJ (2020) One of Big Pharma's biggest players, reveals its COVID-19 vaccine and therapy plans. Science's COVID-19 reporting is supported by the Pulitzer Center, Science, Science Mag.org. 26May, 2020.

[106] Wigginton NS, Cunningham RM, Katz RH, Lidstrom ME, Moler KA, Wirtz D, Zuber MT (2020) Moving academic research forward during COVID-19. POLICY FORUM, Science, Science Mag.org. 28 May 2020: eabc5599. doi: $10.1126 /$ science.abc5599.

[107] Barnes M, Sax PE (2020) Challenges of "Return to Work" in an Ongoing Pandemic. Special Reports, NEJM.org.The New England Journal of Medicine 2020. doi:10.1056/NEJMsr2019953.

[108] Murbun R, Suwarso E, Yuandani (2018) IMMUNOMODULATORY EFFECTS OF ETHANOL EXTRACT OF ARTEMISIA VULGARIS L. IN MALE RATS. Asian J Pharm Clin Res 11(1):245-247. doi:http://dx.doi.org/10.22159/ajpcr.2018.v11s1.26619.

[109] Walker PGT, Whittaker C, Watson OJ, Baguelin M, Winskill P, Hamlet A, et al. (2020) The impact of COVID-19 and strategies for mitigation and suppression in low- and middle-income countries. Science, First release: 12 June 2020,1-18. 10. doi:1126/science.abc0035 (2020).

[110] Stone R (2020) Yemen was facing the world's worst humanitarian crisis. Then the coronavirus hit. Science, Science's COVID-19 reporting is supported by the Pulitzer Center, Science Mag.org. May. 28, 2020. 
[111] Parks JM, Smith JC (2020) How to Discover Antiviral Drugs Quickly. The New England Journal of Medicine, nejm.org. Copyright (C) 2020 Massachusetts Medical Society. May 20, 2020. doi: 10.1056/NEJMcibr2007042.

[112] Kupferschmidt K (2020) Can plasma from COVID-19 survivors help save others? Science's COVID-19 reporting is supported by the Pulitzer Center. ScienceMag.org., Science May 27, 2020.

[113] Gilmore K (2020) Artemisia annua to be tested against COVID-19. ArtemiLife Inc., a US based company, CEO Adam Maust in Artemisia annua fields 2020.

[114] Staff Reporter. (2020) Corona Vaccine will be prepared from the extract of fruits of Aakashmoni plantsOpinion of the researcher of Burdwan. Agnirath News, Burdwan, 15th April 2020,21(8):1-3. Reg.No.WBBEN/2000/2086.

[115] Dutta PK (2020) Covid Toes among kids: New symptom of novel coronavirus infection. News India Today, New Delhi 24th April 2020.

[116] Roy S (2020) Locust attack: A joint fight by India and Pakistan, over the years. The Indian Express, New Delhi, Updated: May 29, 2020.

[117] E TIMES OF INDIA NEWS. (2020) Italy claims to develop first COVID-19 vaccine: Here is the current status of all the potential coronavirus vaccines. TIMESOFINDIA.COM, Health \& Fitness, Last updated on - May 6, 2020.

[118] Blum HE (2020) Personalized Medicine in the Genomics Era. Internal Medicine Review 6(2):1-14.

[119] Raw I (2020) BUTANTAN INSTITUTE: FROM SNAKES TO VACCINES AND ITS DESTRUCTION. Internal Medicine Review 6(3):1-14.

[120] Shah N, Sabia M, Mathur R, Goldberg ME, Wainer I, Torjman M (2020) The Multifaceted Role of IV Ketamine Infusions to Control Depression, Post-Traumatic Stress Disorder, Chronic Regional Pain Syndrome, and Chronic Headaches. Internal Medicine Review 6(3):1-15.

[121] Rajput H (2012) Homeopathic Prophylaxis: Just Homeopathic Vaccination or More. J Homeop Ayurv Med 1:105. doi:10.4172/2167-1206.1000e105.

[122] Werner K, Werner K, Risko N, Burkholder T, Munge K, Wallis L, et al. (2020) Cost-effectiveness of emergency care interventions in low and middleincome countries: a systematic review. Bull World Health Organization 98:341-352. http://dx.doi.org/10.2471/BLT.19.241158.

[123] News. (2020) Homeopathy in managing viral infections like COVID-19. BioSpectrum 10 April 2020.

[124] Mahata CR (2017) Avogadro Limit Washed out by Nano-Associates of Water which Continue as Information Carriers in Serial Dilutions and End up with Generalized Concept of Medicines. International Journal of Complementary \& Alternative Medicine 9(4):00305. doi: 10.15406/ijcam.2017.09.00305.

[125] Kaiser J (2020) To streamline coronavirus vaccine and drug efforts, NIH and firms join. Science, ScienceMag.org. 17th April 2020.

[126] NIH. (2017) Clinical Alerts and Advisories /Disclaimer. U.S. National Library of Medicine, ClinicalTrials.gov. This page last reviewed in September 2017. https://www.nih.gov/coronavirus and https://www.coronavirus.gov.

[127] Sherwood L (2020) Childhood vaccines may help protect against COVID-19 mortality. Science Advisory Board contributing writer, Copyright (C) 2020 scienceboard.net, published commentary in mBio. June 22, 2020.

[128] Onyema EM, Eucheria NC, Obafemi FA, Sen S, Atonye FG, Sharma A, Alsayed AO (2020) Impact of Coronavirus Pandemic on Education. Journal of Education and Practice 11(13):108-121.

[129] Baumi F, Narayani R, Sanders D, Patel V, Quizhpe A (2009) Social vaccines to resist and change unhealthy social and economic structures: a useful metaphor for health promotion. Health Promotion International 24(4):428-433. doi:10.1093/heapro/dap026.

[130] Bell IR (2020) The Complexity of the Homeopathic Healing Response Part 1: The Role of the Body as a Complex Adaptive System in Simillimum-Initiated Recovery from Disease. Homeopathy 109:42-50.

[131] Bell IR (2020) The Complexity of the Homeopathic Healing Response Part 2: The Role of the Homeopathic Simillimum as a Complex System in Initiating Recovery from Disease. Homeopathy 109:51-64.

[132] The Science Advisory Board Net. (2020a) Fighting SARS-CoV-2 at the bench? Express Cells has your back. Letter Science Advisory Board.Net on Fri, 24 Apr 2020,18:30:49. <letters@scienceboard.net>

[133] Abdelrahman Mohamed Yehia TY, El-Ashry S, El-Batoty K, El-Hady S (2019) Efficiency of Triple Antibiotic Mixture and Propolis as Intracanal Medication in Revascularization process in immature apex: A clinical study. Glob J Medical Clin Case Rep 6(2):019-025. doi: http://doi.org/10.17352/2455-5282.000073. 
Acacia Auriculiformis-Extract Synthesis PR-Proteins Developed Potential Biomedicines-Vaccine Against Okra-Diseases and Covid-19: Improved Science Technology Communications Bio-Economy Applications

[134] The Science Advisory Board Net. (2020b) Bulk Antibody Production to Support COVID-19 Research \& More. Are You Involved in COVID-19 (SARS-CoV-2) Research? Let's Work Together. Letter Science Advisory Board.Net on Mon, 04 May 2020. <letters@scienceboard.net>

[135] Sharma S, Sibi G (2020) Flavonoids from Carica papaya Linn. against SARS-CoV-2 protease: Molecular Docking and ADME analysis. G Med Sci 1(1): 037-046.

[136] Levin M (2020) Childhood Multisystem Inflammatory Syndrome - A New Challenge in the Pandemic. The New England Journal of Medicine. This editorial was published on June 29, 2020, at NEJM.org. doi: 10.1056/NEJMe2023158.

[137] Cohen J (2020) The line is forming for a COVID-19 vaccine. Who should be at the front? Science's COVID-19 reporting is supported by the Pulitzer Center, Science, Jun. 29, 2020, 5:30 PM. doi:10.1126/science. abd5770.

[138] Silver RC (2020) Surviving the trauma of COVID-19. Editorial, SCIENCE, sciencemag.org, 3JULY 2020,369(6499):11. doi:10.1126/science. abd5396.

[139] Cornwall W (2020) COVID-19 Officials gird for a war on vaccine misinformation. SCIENCE, sciencemag.org, 3JULY 2020.

[140] Chitguppi R (2020) Paradigm shift in our focus from B-cell response to T-cell response against SARS-CoV-2. Preprint June 2020, 10.13140/RG.2.2.14498.25283. Publication at doi: https://www.researchgate.net/publication/342420660.

[141] Datta SC (2020d) Okra maybe potential cost-effective personalized-biomedicines social-vaccine against COVID-19: Improved immunity food-security green-economy science-and-technology-communication applications. Innovative Journal of Medical Sciences 4(2):5-20. Available Online at www.ijms.co.in

[142] Datta SC (2020e) Biomedicines-Cina Against Covid-19: Controlled Plant Diseases Enriched Science and Technology Communication Green Economy. International Journal of Research -GRANTHAALAYAH 8(09): 234 - 255. https://doi.org/10.29121/granthaalayah.v8.i9.2020.1537

[143] Datta SC (2020f) NGO Act as Potential-Policy-Developer Social-Vaccine-COVID-19 Epidemic-Model until Discovery-of-Medical-Vaccine: Achieved Green-Socio-Economic Welfare Science Technology Innovations. Arch Community Med Public Health 6(2): 225-232. https://dx.doi.org/10.17352/2455-5479.000111.

[144] Datta SC (2020g) Potential Policy-Developed Global-COVID-19-Vaccine: Enriched Medical Sciences and Technology Green-Socio-Economy. Cross Current Int J Med Bioscience 2(10): 1-12.

[145] Datta SC (2020h) Intercropped Cowpea Maybe Use as Biomedicine Improved Immunity against COVID-19: Enriching Science and Technology Communication Applications Food Security Economy. Diagn Ther Complement Tradit Med (Early Online in Progress). https://ospopac.com/journals/All.

[146] Krause PR, Gruber MF (2020) Emergency Use Authorization of Covid Vaccines - Safety and Efficacy Followup Considerations. PERSPECTIVE, The NEW ENGLAND JOURNAL of MEDICINE. Copyright (C) 2020 Massachusetts Medical Society. 